\title{
An integrated framework of coastal flood modelling under the failures of sea dikes: a case study in Shanghai
}

\author{
Qian Ke ${ }^{1}$. Jiangshan Yin ${ }^{2}$ Jeremy D. Bricker ${ }^{1,3}$ (D) . Nicholas Savage ${ }^{4}$. \\ Erasmo Buonomo ${ }^{4}$. Qinghua $\mathrm{Ye}^{1,5} \cdot$ Paul Visser $^{1} \cdot$ Guangtao Dong $^{6} \cdot$ Shuai Wang $^{7}$. \\ Zhan Tian $^{8} \cdot$ Laixiang Sun $^{9,10} \cdot$ Ralf Toumi $^{7} \cdot$ Sebastiaan N. Jonkman ${ }^{1}$
}

Received: 16 January 2021 / Accepted: 5 June 2021 / Published online: 23 June 2021

(C) The Author(s) 2021

\begin{abstract}
Climate change leads to sea level rise worldwide, as well as increases in the intensity and frequency of tropical cyclones (TCs). Storm surge induced by TC's, together with spring tides, threatens to cause failure of flood defenses, resulting in massive flooding in lowlying coastal areas. However, limited research has been done on the combined effects of the increasing intensity of TCs and sea level rise on the characteristics of coastal flooding due to the failure of sea dikes. This paper investigates the spatial variation of coastal flooding due to the failure of sea dikes subject to past and future TC climatology and sea level rise, via a case study of a low-lying deltaic city- Shanghai, China. Using a hydrodynamic model and a spectral wave model, storm tide and wave parameters were calculated as input for an empirical model of overtopping discharge rate. The results show that the change of storm climatology together with relative sea level rise (RSLR) largely exacerbates the coastal hazard for Shanghai in the future, in which RSLR is likely to have a larger effect than the TC climatology change on future coastal flooding in Shanghai. In addition, the coastal flood hazard will increase to a large extent in terms of the flood water volume for each corresponding given return period. The approach developed in this paper can also be utilized to investigate future flood risk for other low-lying coastal regions.
\end{abstract}

Keywords Tropical cyclone $\cdot$ Sea level rise $\cdot$ Climate change $\cdot$ Coastal flooding $\cdot$ Dike failure

\section{Introduction}

Climate change leads to sea level rise (SLR) and also intensification of tropical cyclones (TC's) worldwide (Bhatia et al. 2019; Holland and Bruyère 2014; Knutson et al. 2015). Studies show that the frequency of TC's will increase in most locations over the twenty-first

Jeremy D. Bricker

J.D.bricker@tudelft.nl; jeremydb@umich.edu

$\triangle$ Zhan Tian

tianz@sustech.edu.cn

Extended author information available on the last page of the article 
century (Bhatia et al. 2018), especially in the western North Pacific (Emanuel 2013; Warner and Tissot 2012). Storm surge (SS) is a complex function of TC characteristics (e.g. storm size and forward speed) (Irish et al. 2008; Rego and Li 2009) and coastal geometry and bathymetry (Lin et al. 2012; Resio and Westerink 2008). SS is driven by surface wind and sea level pressure fields (Lin et al. 2012). Among these, wind stress plays a dominant role $(\sim 90 \%)$ in generating surge over broad, shallow continental shelves; thus the increasing intensification of TC's will lead to higher SS (Ali 1999). Therefore, flooding due to SS in combination with spring tide is projected to become more frequent and severe in coastal areas (Mousavi et al. 2011; Woodruff et al. 2013). TC's in the northwest Pacific basin are called typhoons (Needham et al. 2015). Mei and Xie (2016) found that typhoons that strike East Asia have intensified by $12-15 \%$ in the period 1977-2014 and typhoons striking eastern mainland China will further intensify with the projected ocean surface warming pattern under increasing greenhouse gas forcing. In recent years, typhoon-induced flooding has caused massive economic damage and posed great threats to residents in coastal areas (Acosta et al. 2016; Pham et al. 2018; Yin et al. 2013a). Typhoon Haiyan (2013) resulted in 6300 deaths, 1061 missing and 28,689 injured in the Philippines (Lagmay et al. 2015). Typhoon Hagibis (2019) caused at least 80 deaths, and affected 135,000 people (Tay et al. 2020) and substantially damaged coastal infrastructure in Japan (Shimozono et al. 2020). Therefore, it' is important to carry out quantitative assessment of the potential risk of TCinduced SS and flooding for densely populated cities and river deltas (Walsh et al. 2016).

Under the context of climate change, coastal flooding associated with land-falling TC's depends both on SLR and TC intensity (Woodruff et al. 2013). Global SLR is projected to be $0.59-1.1 \mathrm{~m}$ under the RCP8.5 scenario by the end of this century. Beyond 2050, the rise rate of global sea level is projected with large uncertainty due to continuing deep ocean heat uptake and mass loss of the Greenland and Antarctic ice sheets. Meanwhile, studies show with high confidence that sea level will remain elevated for thousands of years (IPCC 2019). Furthermore, land subsidence is the most important cause of future changes in relative sea level (RSL) in many delta regions (IPCC 2019). A recent study showed that a total of $68 \%$ of the global coastal flooded area will be caused by tide and storm events exacerbated by projected regional SLR (Kirezci et al. 2020). Apart from SLR, the impacts of climate change on TC climatology have been given special attention due to the uncertainty embedded in the TC system. Woodruff et al. (2013) highlighted that joint consideration of TC climatology, RSLR and shoreline change is crucial for accurate assessment of future flood risks. Lin et al. (2012) studied the combined effect of storm climatology change and SLR, and presented that the return period of SS flooding will be largely reduced (in other words, events will be more frequent) in New York City by the end of the century. In addition, a recent study stressed that the effect of TC climatology change is likely to be larger than the effect of SLR for over $40 \%$ of coastal counties in the Gulf of Mexico (Marsooli et al. 2019). Besides the dynamic characteristics of these external forcing factors, however, few studies of coastal flooding have taken into account the effects of failure of coastal flood defences which were designed to protect the inland area from the sea. Yin et al. (2020) combined reliability analysis with hydrodynamic modelling to quantify the effect of projected RSLR on dike failures and flood hazard for Shanghai while neglecting the change of storm climatology. In order to study coastal flood hazard under climate change, this paper intends to develop a hydrodynamic modelling framework to investigate coastal flooding considering the failure of dikes, and further analyses the individual and combined effects of climatology change and RSLR. This is done for the case study of the Shanghai coastal area, one of the most flood-exposed megacities in the world (Hanson et al. 2011). This is the first study and application of storm climatology change in the Yangtze Estuary area. 
This paper is structured as follows. Section 2 describes the study area, including typhoons under past and future climate scenarios, SLR and land subsidence. Section 3 introduces the boundary conditions computed by a hydrodynamic model and a model for overtopping and failure of coastal dikes. Section 4 discusses the resulting coastal overland flooding under past and future climates. Section 5 presents the conclusions.

\section{Study area}

\subsection{Sea dike}

Shanghai is located in the estuary of the Yangtze River, on the western boundary of the East China Sea. It is a metropolis with a population of 24 million in 2018 (SSB 2019). It is ranked as one of the top 10 cities in the world in terms of expected population and assets exposed to coastal flooding by the 2070s (Hanson et al. 2011) and the most vulnerable city to coastal flooding worldwide by 2100 (Balica et al. 2012). Due to its low-lying flat topography, about $85 \%$ of the territory is prone to both astronomical high tides and a frequent occurrence of storm surges (Du et al. 2020). On average, Shanghai is affected by typhoons 2-3 time a year (Zong and Chen 2002). The induced SS is typically $\sim 1 \mathrm{~m}$ (highest record: $1.86 \mathrm{~m}$ ), combined with a high astronomic tide of 2-3 m above m.s.l, flooding would occur regularly if no dikes were built along the coast. With the protection of sea dikes, Shanghai is designed to withstand storms of occurrence probability of 1/100-1/200 per year (p.y.) in the coastal area. In the past, Typhoon Gloria (1949) impacted Shanghai coincident with a spring tide. $40 \mathrm{~km}$ of sea dikes were damaged along the Pudong coast and completely breached over more than $10 \mathrm{~km}$ (Shen, 1997). However, the construction standard of the sea dikes was quite different from now. The current crest height of the sea dike was measured through a field investigation by the authors in September 2019. It was found that the height of dikes at Jinshan was generally higher than those at Pudong district (seeFig. 1), despite Pudong being a newly developed area with critical infrastructures (such as PVG airport) to protect. However, high dike crest heights at Jinshan are also needed to protect economically important areas like the SINOPEC industry. These dikes were constructed in the 1990s and are regularly inspected and maintained by local authorities. So far (since 2000), there has been no report of failure of a coastal dike in the Shanghai area.

Nonetheless, owing to SLR and land subsidence, typhoon-induced SS and wave set-up pose a wave overtopping threat to the sea dikes. The length of dike which can be overtopped will increase $46 \%$ by 2100 in Shanghai (Wang et al. 2011). Overtopping may not only result in flooding, but also put sea dikes at risk of breaching. Overtopping-induced dike breaching is one of the most frequent causes of coastal dike failure, and this can potentially cause tremendous damage to the local community (Liang et al. 2020).

\subsection{Typhoons under climate change}

SS from typhoons under historical and future climates is evaluated using pressure and wind fields generated by a meteorological model. The predictability of TCs is affected by small scale processes, in particular for their intensities (Zhang et al. 2014), although there is evidence of improvements by increasing meteorological model resolution to the scale of few kilometres, which allows explicit resolution of some deep convection processes. Similar considerations are valid for TC projections under climate change; very high resolution 


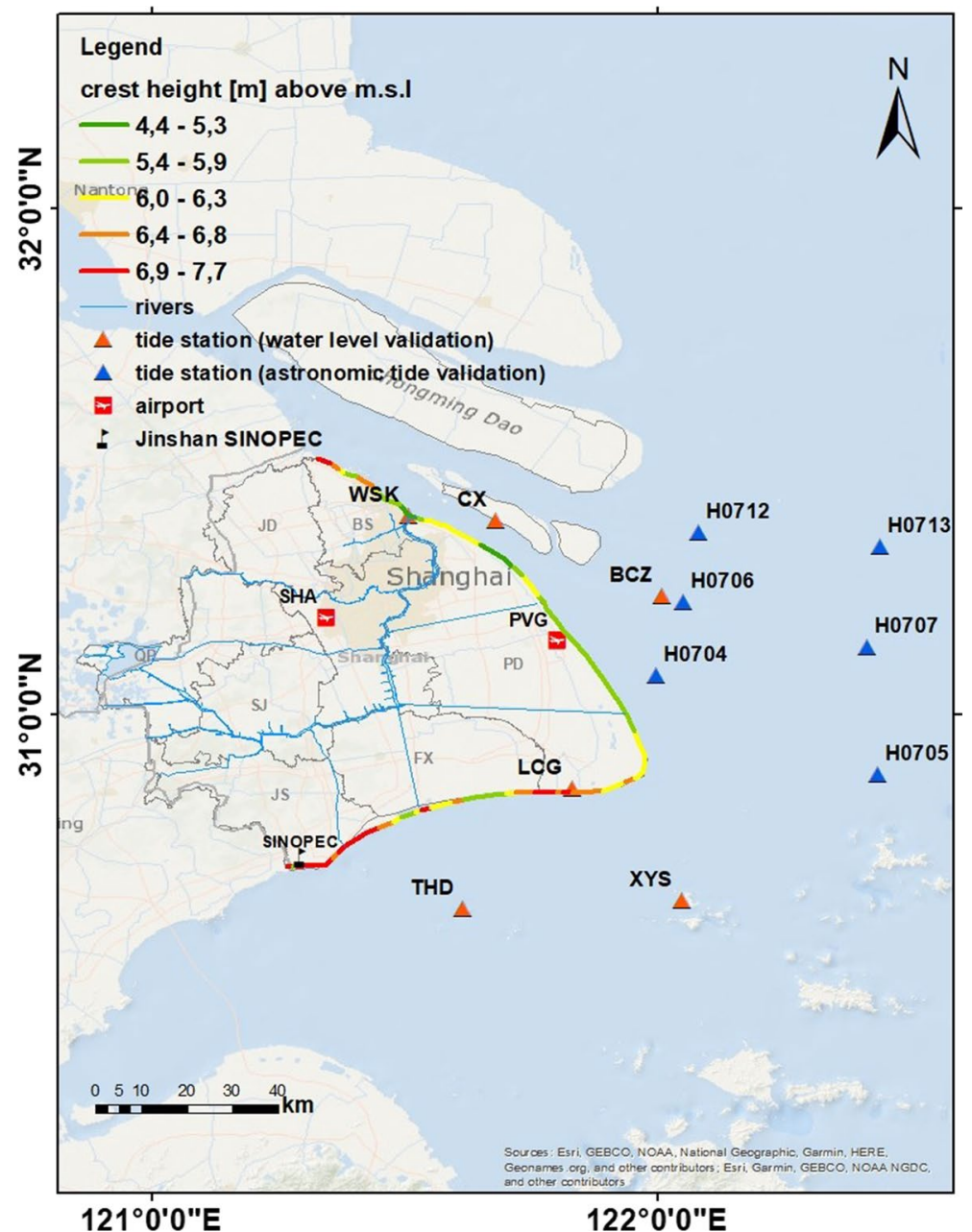

Fig. 1 Geographical location of tide stations and sea dikes along the coast of mainland Shanghai (excluding Islands). The crest height of the sea dike was measured by the authors in 2019. (District names: JS-Jinshan, FX-Fengxian, PD—Pudong, BS—Baoshan, JD—Jiading, SJ-Songjia, QP-Qingpu)

might be needed to represent changes in physical processes under the perturbed climate (Gutmann et al. 2018).

The climate projections for TCs used in this study are based on a downscaling experiment using the Regional Atmosphere and Land (RAL) configuration for kilometre scale modelling (Bush et al. 2020), with the settings of the mid-latitude climate configuration of UK Climate Prediction 2018 (Fosser et al. 2020), referred to as HadREM3-RA1M. The model has been run at a resolution of $4 \mathrm{~km}$ and without including a parameterized convection scheme, which are then exclusively represented by the model dynamics. This experimental set-up also includes an intermediate nest at $12 \mathrm{~km}$ resolution, expected to fill the gap between the typical resolution of General Circulation Model ( $>100 \mathrm{~km})$ and the $4 \mathrm{~km}$ resolution of the convection permitting model (Leduc and Laprise 2009; 
Matte et al. 2017). The resulting double nesting set-up has shown improved skill in sensitivity tests with respect to the single nesting option (Fosser et al. 2019).

The design of the double nesting experiment over Southern China is aimed at optimizing the representation of TCs in this area. For this purpose, the $12 \mathrm{~km}$ external domain includes a large fraction of the Western Pacific in order to capture the main cyclogenesis regions to ensure that all the TCs imported at the boundary of the $4 \mathrm{~km}$ domain have fully developed at the $12 \mathrm{~km}$ resolution, while the $4 \mathrm{~km}$ domain has been set by placing the region of interest toward the centre of the domain to avoid numerical effects at the boundaries and the development of fully resolved storms at $4 \mathrm{~km}$ resolution. The climate projections used to generate boundary conditions for this double nesting experiments have been taken from the Hadley Centre model HadGEM2-ES (Collins et al. 2011) simulations included in the Coupled Model Intercomparison Project (Taylor et al. 2012) model. In particular, two 20-year time slices have been simulated, with the baseline taken from the historical simulation for the period 1981-2000, and the future projection from the RCP8.5 forcing scenario (Moss et al. 2010) for the period 2080-2099. The RCP8.5 pathway was developed to explore a high-risk future; given the user requirements of this project, it was decided to select the RCPs that we considered the most conservative for decision makers. The configurations of these two HadGEM2ES simulations have been described in Jones et al. (2011). In this context, it is worth mentioning the good comparison with observations of large-scale circulation relevant for TC formation and evolution, and sea surface temperature (SST) for the historical run.

Results from the $4 \mathrm{~km}$ simulations driven by the historical HadGEM2-ES projections have shown good frequency of events with respect to observed tracks and an improvement in the representation of TC intensities with respect to the coarser resolution models, while the results for the future simulation under the HadGEM2-ES show a strong increase in intensity, expected from the strong SST warming $(\sim 3.5 \mathrm{~K})$ in the Western Pacific projected from the HadGEM2-ES simulations (which are prescribed in the double nesting experiment). The $4 \mathrm{~km}$ simulation model created 111 and 103 typhoon events in the past period and future periods, respectively. Figure 2 shows the trajectories of all the modelled typhoons in the past period and under the RCP 8.5 scenario in the future period. The surface wind and air-pressure fields were then converted into
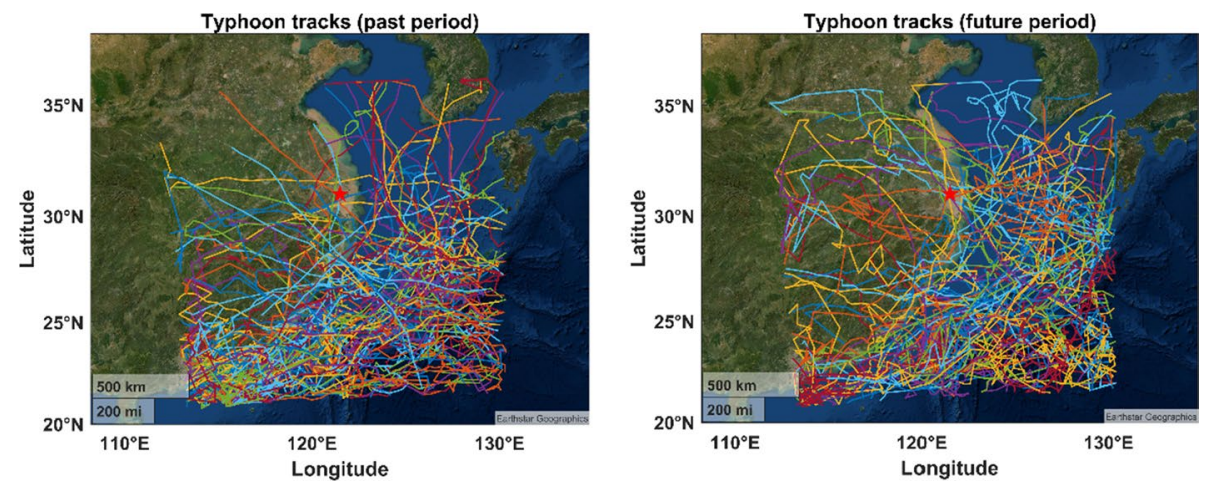

Fig. 2 Trajectories of the modelled typhoons in the past period 1980-2000 and under the RCP8.5 climate scenario in the future period of 2080-2099 (red star represents the location of Shanghai city) 
spiderweb format (Deltares 2021), which is used as metrological forcing for the hydrodynamic and wave models.

\subsection{Sea level rise and land subsidence}

IPCC (2019) predicts a median global mean sea level rise of $84 \mathrm{~cm}$ (RCP 8.5) by 2100 relative to the period 1986-2005. During the last 30 years, absolute sea level has risen at a mean rate of $3.8 \mathrm{~mm} /$ year in Shanghai, which is higher than the global and national average rates (Yin et al. 2013b). The China Sea Level Bulletin (Ministry of Natural Resource of China 2019) projects 75-155 mm SLR by the end of 2050, relative to 2018, in Shanghai. Following previous research on the prediction of SLR in Shanghai (Wang et al. 2018), we set the absolute sea level rise to $75-90 \mathrm{~cm}$ with a median estimate of $82.5 \mathrm{~cm}$ in the period 2081-2099 with respect to the baseline year of 2010 .

Moreover, local anthropogenic subsidence is currently the most important contributor to future changes in RSL at the coast (IPCC 2019). Shanghai has experienced large-scale land subsidence since the beginning of twentieth century (He et al. 2019). This causes the coastal protection works (e.g. earth and rock filled sea dikes) to deform and malfunction. In the central metropolitan area, the land subsidence rate reached approximately 25-60 mm/year during 1995-2001 (Wang et al. 2018). The land subsidence rate was controlled by recharging groundwater to aquifers after this period. In the future, the average subsidence rate is estimated at $6 \mathrm{~mm} /$ year $\pm 1 \mathrm{~mm} /$ year (Yin et al. 2013b). In this research, the accounted land subsidence for sea dike deformation is estimated as $30-42 \mathrm{~cm}$ with a median estimate of $36.5 \mathrm{~cm}$ in the period 2081-2099. In our analysis, the RSLR (absolute SLR plus land subsidence) was taken into account in the parameters of calculation of overtopping discharge rate (i.e. crest height, berm elevation, crown wall elevation and toe elevation of dike).

\section{Model set-up and validation}

A hydrodynamic model and a wave model in the East China Sea were established to calculate the hydraulic boundary conditions needed to estimate overtopping and breaching flow discharge during the typhoons. Given the calculated time series of (overtopping and breach) flow discharge at specific locations along Shanghai's sea dike, flood extent and depth were computed based on an overland flooding model. The analysis is conducted via the following steps:

Step 1 coastal hydrodynamic model set-up and validation against astronomical tides and historical typhoon storm tide.

Step 2 wave model set-up and validation against measurements from a historical typhoon.

Step 3 overtopping discharge rate calculation for hypothetical typhoons under past and future climates.

Step 4 breach discharge calculation for hypothetical typhoons under past and future climates.

Step 5 flood inundation model set-up and simulation with hypothetical typhoons under past and future climate scenarios. 
Overtopping is taken as the main failure mechanism of the sea dikes and it is also assumed to be the main reason for any potential dike breach. The overtopping discharge is calculated empirically, then used to drive the overland flood model. More details for each model will be explained in the following sub-sections.

\subsection{Storm surge model}

D-Flow Flexible Mesh (DFM) (Deltares 2020) is based on the numerical solution of Reynolds averaged shallow water equations for incompressible free surface flow. The spatial discretization of the equations in DFM, which adopts a mix of structured and unstructured grids, is performed using a cell-centred finite volume method. Time integration for the advection terms of the shallow water equations is performed using an explicit scheme, and time integration for the barotropic terms uses an implicit scheme to improve efficiency (Kernkamp et al. 2011). Due to the stability restriction of using an explicit scheme, a dynamic time step is adopted whereby the model specifies the time step for each computational step to help maintain model stability and performance. This model has the capability to run on a highly flexible unstructured grid allowing fluid motion over a complex coastal geometry. It has a proven capability to simulate tidal circulation and SS propagation in complex coastal environments with a high degree of accuracy (Kernkamp et al. 2011; Symonds et al. 2017; De Goede 2020).

The hydrodynamic model is validated against measured astronomical tides and measured storm tides (astronomical tide plus SS). The domain of the model covers the East China Sea, Hangzhou Bay (HZB), the Yangtze Estuary (YE), the downstream reach of the Yangtze River, and river networks in Shanghai, roughly ranging from 24 to $34^{\circ} \mathrm{N}$ and $118^{\circ} \mathrm{E}$ to $128^{\circ} \mathrm{E}$, and consists of 69,000 mesh cells (see Fig. 3). Bathymetry data comes from local refined digitized bathymetry (Wang et al. 2018) and GEBCO14 (http://www. gebco.net). Depths of the river and canal networks were provided by the Shanghai Water Authority (surveyed in the 2010's). A Manning's $\mathrm{n}$ of $0.026 \mathrm{sm}^{-1 / 3}$ is applied in the East China Sea and $0.012-0.022 \mathrm{sm}^{-1 / 3}$ is applied in the Yangtze Estuary and near shore. Discharge at the Yangtze River boundary (see Datong station in Fig. 3) was assumed to be $31,000 \mathrm{~m}^{3} / \mathrm{s}$, based on the average daily measured flow during the period 1998-2015 (provided by Yangtze Estuary Hydrology and Water Resources Survey Bureau). Astronomical tidal elevations on the open boundaries applied harmonics from the OTIS regional solution (Egbert and Erofeeva 2002). For the storm tide case, the proposed wind drag coefficients (Chu et al. 2019) were used based on Zijlema et al (2012) adapted from Smith and Banke (1975).

The astronomical tide was validated by comparing model output to observations at tide stations (see Fig. 1) near Shanghai during non-typhoon periods. Measured hourly tide data on 22-23 July and 29-30 July in 2007 were obtained from the State Key Laboratory of Estuarine and Coastal Research at East China Normal University. Results of this validation are shown in Fig. 13 (see Appendix 1). The height datum is respect to 1985 Chinese National datum. The station-averaged root mean square error (RMSE) is $0.16 \mathrm{~m}$, with a 0.98 correlation coefficient (CC), indicating a good performance of tide prediction.

Storm tide (with meteorological forcing provided by the Shanghai Climate Center, Shanghai Meteorological Service) is validated against hourly water level measurements during Typhoon Winnie in 1997. Figure 14 shows good agreement between the measured and modeled water levels at Wusongkou(WSK), Beichaozhong(BCZ), Changxing(CX), Luchaogang(LCG), Tanhudao(THD) and Xiaoyangshan(XYS) (see storm tide location in 


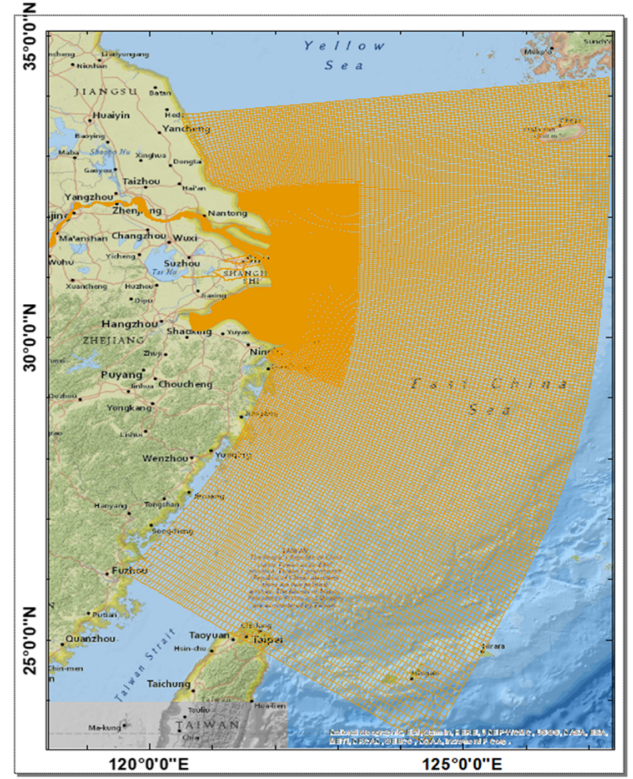

(a)

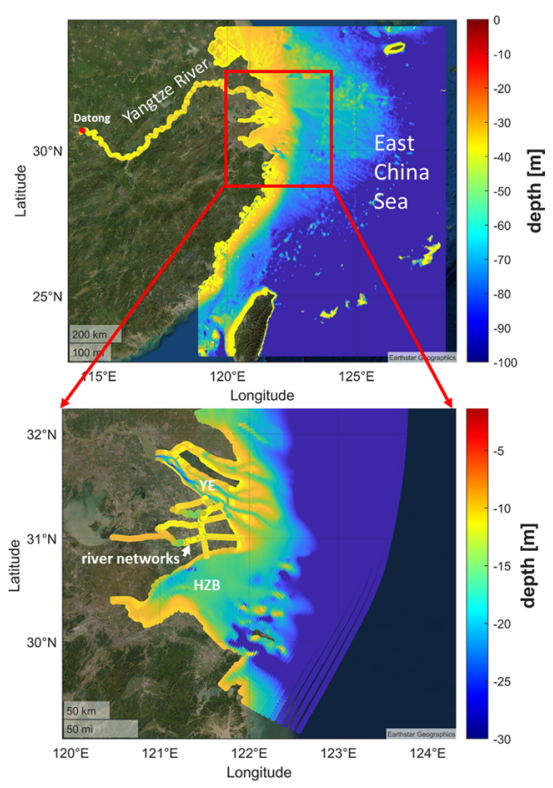

(b)

Fig. 3 Model domain a Combination of triangular and curvilinear grids and $\mathbf{b}$ bathymetry including East China Sea shelf, Yangtze river bed, Hangzhou Bay (HZB), Yangtze Estuary (YE) and domestic rivers (river networks) in Shanghai city

Fig. 1). The average RMSE of these stations is $0.4 \mathrm{~m}$, with a 0.96 correlation coefficient (CC). The highest storm tide, which dominates overtopping, is simulated well. Low-tide troughs in water level at some times were underestimated, likely due to bathymetric data that did not exactly match the actual state of the seabed in 1997, as the nearshore water depth is strongly affected by dredging the navigation channel and modification of sediment loading of the Yangtze River. However, these low tides do not have a strong impact on overtopping of the coastal dike. The astronomical and storm tide validation results show that the DFM SS model has capability to predict reasonable water levels along the coast of Shanghai during typhoons.

\subsection{Wave model}

Waves were simulated by a numerical model-SWAN, which is a spectral wave model that solves the wave action balance equation. In SWAN, the wave direction space was equally discretized into 36 bins and wave frequency space was logarithmically distributed into 24 bins with a range of $0.05-1.0 \mathrm{~Hz}$. Bottom friction was based on the empirical JONSWAP formulation with a friction coefficient $0.038 \mathrm{~m}^{2} \mathrm{~s}^{-3}$ (Zijlema 2010). Quadruplet and triad wave interactions were both activated with default values. The domain of the SWAN model is similar to that of the hydrodynamic model. Two nested, structured grids were used (see Fig. 4). The larger domain is the same as the coarse resolution SS model; the nested part is more detailed and closer to the Shanghai coast with a resolution of $30 \mathrm{~m}$. Other input data are identical to that of the hydrodynamic model. 


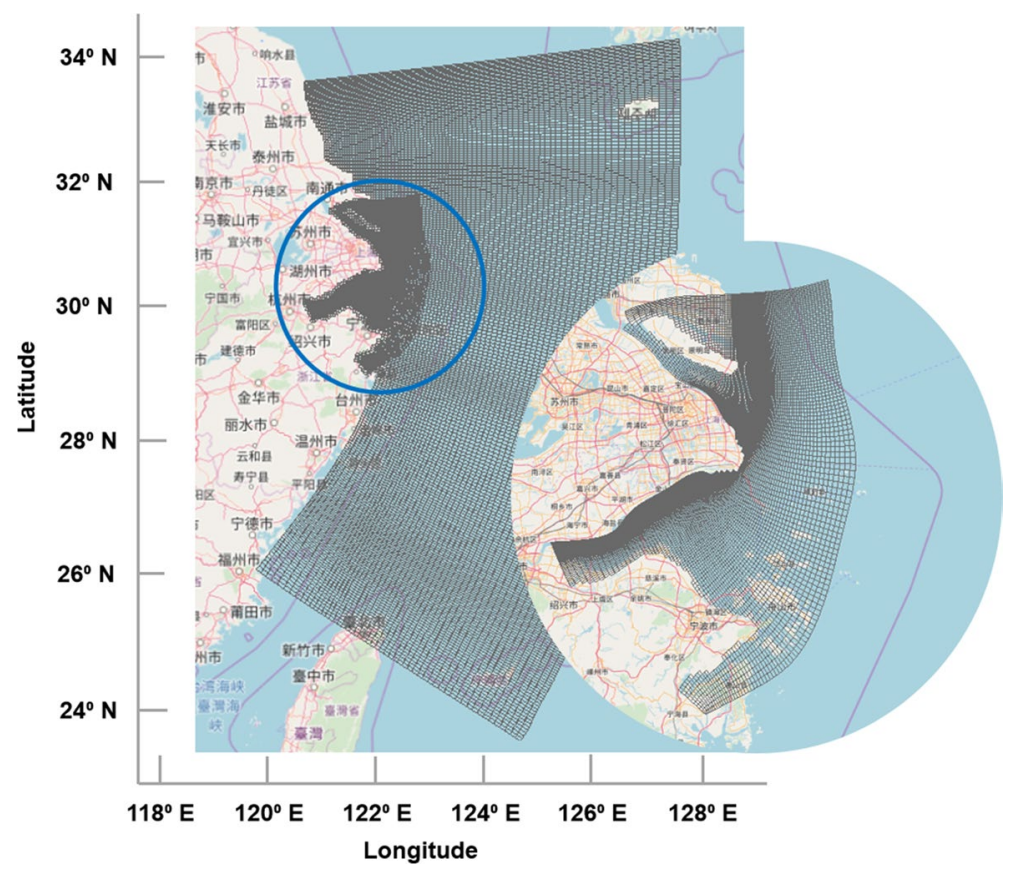

Fig. 4 Nested computational grid for the wave model

The wave model was validated against 6-hourly observations from a buoy $\left(123.59^{\circ} \mathrm{E}\right.$, $29.29^{\circ} \mathrm{N}$ ) digitized from Ge et al. (2013) during Typhoon Shikula in 2002. Winds and pressure input to the model are from the Japan Meteorological Association (JMA) storm track, spatialized by the Holland model (Holland et al. 2010). A validation of wind speed was conducted by Yin et al. (2020). Figure 15 shows the resulting significant wave height and peak period, which agree well with measurements, with RMSE of $0.7 \mathrm{~m}$ and $1.9 \mathrm{~s}$, respectively. Breaking-wave-induced water level set-up is approximated as $5 \%$ of the significant wave height at the shoreline (Feng et al. 2011; Yamanaka et al. 2020).

\subsection{Overtopping}

The coastal area of Shanghai is protected by various sea dikes that generally consist of a revetment on the outside slope, a crown wall, and an inner slope consisting of grass and clay (see Fig. 5).

An empirical model (see Eq. 1)) from the Chinese Guideline of Dike Design (GB/T 51015-2014) is used to estimate wave overtopping discharge, with physical quantities defined as shown in Fig. 5. We assume all the dikes have good quality of grass cover on the inner slope, with clay-filled geo-bags underneath.

$$
q=0.07^{\frac{R_{c}}{H_{s}}} \exp \left(0.5-\frac{b_{1}}{2 H_{s}}\right) B K_{A} \frac{H_{s}}{T_{p}}\left[\frac{0.3}{\sqrt{1 / \tan \alpha}}+\tan h\left(\frac{d}{H_{s}}-2.8\right)^{2}\right] \log \sqrt{\frac{g T_{p}^{2}}{2 \pi H_{s} \tan \alpha}}
$$




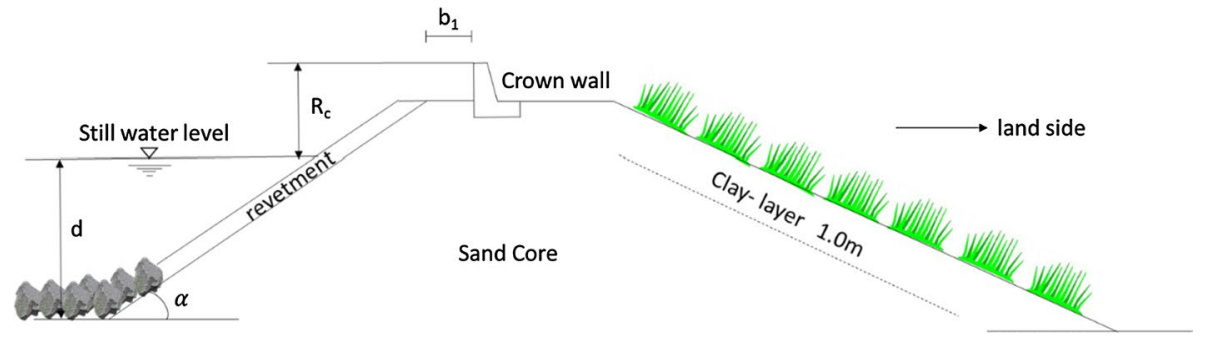

Fig. 5 An example cross section of sand sea dikes (Yin et al. 2020)

where $\mathrm{KA}-$ influence factor for roughness on the slope [-]; this value is suggested as 1.0, $0.49,0.4,0.5$ for revetment material of concrete slabs, riprap, dolos, and hollow squares, respectively., Hs - Significant wave height at toe of the structure [m], d-Water depth at toe of the structure [m], g-Gravity acceleration [m/s2], Tp-peak period [s], Tan $\alpha$ - outer slope [-], $R_{c}$ - freeboard between still water level and crown wall crest $[\mathrm{m}], b_{l}$ - distance from crown wall to seaward edge of dike crest [m], $B$-empirical factor [-]; this value is suggested as $0.6,0.25,0.38$ when the value of $\tan \alpha$ is $1 / 1.5,1 / 2,1 / 3$, respectively.

$H_{\mathrm{s}}$ is assumed to be $85 \%$ of the model result (of significant wave height) nearshore to account for wave breaking in shallow water before the toe of the dike (Van der Meer and Janssen 2002). The empirical parameter $B$ is a function of slope $m$, where $B=0.38$ for $m=3$. The empirical parameter $K_{\mathrm{A}}$ is a function of revetment type, where $K_{\mathrm{A}}=1.0$ for a concrete slab. $H_{\mathrm{m} 0}$ is incident significant wave height, and $T_{\mathrm{p}}$ is peak period.

To validate the overtopping calculation, Typhoon Winnie (1997) was simulated as described in Sect. 3.1, with the addition of the wave model and overtopping calculation. Figure 6 shows a maximum overtopping discharge value of $0.13 \mathrm{~m}^{3} / \mathrm{s} / \mathrm{m}$ in Fengxian district. Overtopping at Pudong and Jinshan was calculated as $0.1 \mathrm{~m}^{3} / \mathrm{m} / \mathrm{s}$ and $0.04 \mathrm{~m}^{3} / \mathrm{m} / \mathrm{s}$,

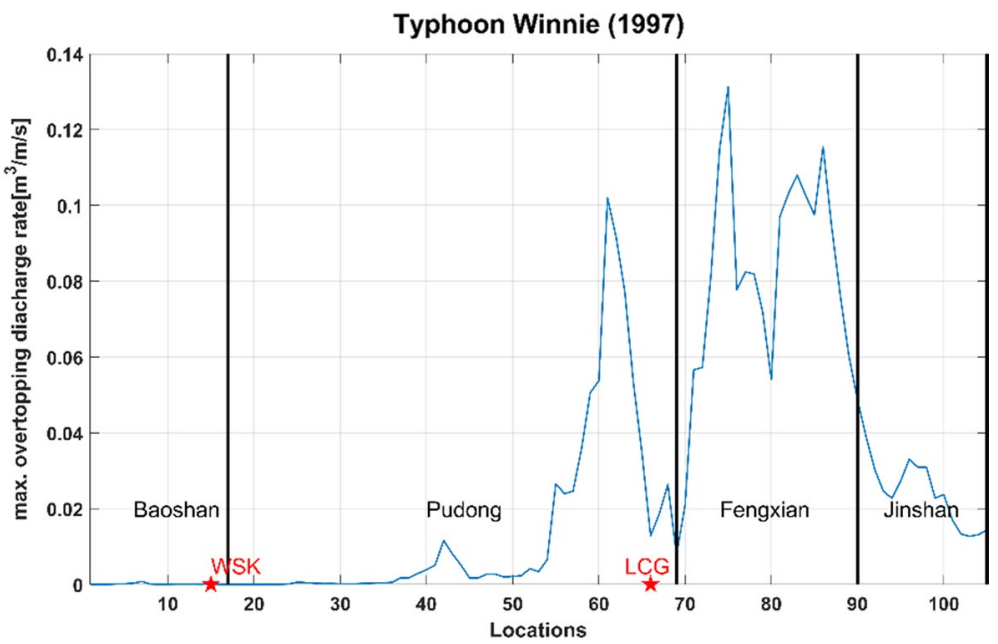

Fig. 6 Simulated maximum overtopping discharge along the Shanghai sea dike during Typhoon Winnie in 1997 (105 calculation points were evenly distributed along the coast; the locations of WSK and LCG is shown by red stars on the $\mathrm{X}$-axis) 
respectively. This result is consistent with descriptions of overtopping of sea dikes during this typhoon (Xu 2006). It was reported that dikes were overtopped over a length of about $22.6 \mathrm{~km}$ at Fengxian and more than 10 locations along the sea dike were breached in Shanghai in 1997.

In China, the maximum overtopping discharge the dike can withstand without damage is typically assumed to be $0.01-0.05 \mathrm{~m}^{3} / \mathrm{m} / \mathrm{s}$ depending on the construction material of the front and rear slopes of the revetment and state of maintenance. Zhang et al. (2017) tested dike breaches by physical experiments in China. It was found that Chinese sea dikes will be completely unstable and then breach at an overtopping discharge of $0.117-0.424 \mathrm{~m}^{3} / \mathrm{m} / \mathrm{s}$. During our field investigation of the sea dike in Shanghai, it was found that the revetment on the outer slope is mostly concrete, and the grass cover on the inner slope is generally in good condition. Additionally, considering Shanghai's important economic position in China, the sea dike is assumed to be well maintained at the present time. Therefore, $0.2 \mathrm{~m}^{3} / \mathrm{m} / \mathrm{s}$ was taken as a threshold for further study (of breaching). This value is a metric for the overtopping resistance of the inner slope. It should be noted that overtopping is assumed to be the main cause of dike breaching in this paper. Locations that experience large overtopping discharge that exceeds a predefined threshold are expected to be the breaching locations.

\subsection{Dike breach}

According to Visser (1998b), there are three types of breaches distinguished by different geometrical and material conditions. When vertical erosion at the breach inflow is prevented or slowed down by a solid dike foundation (for instance a solid clay layer), by a solid berm structure on the dike outer slope, by solid toe protection on the dike outer slope, or by a solid and relatively high foreland (i.e. a pavement or solid clay ground), a Type A breach (shown in Fig. 7) takes place. Since the Shanghai dikes have solid berms with forelands, a type A breach is assumed in this paper.

The breach flow discharge is calculated with the broad-crested weir formulae (Visser 1998b).

$$
Q_{b r}=m \sqrt{g} B\left(H_{w}-H_{p}\right)^{1 / 2}\left(H_{p}-Z_{b r}\right)
$$

or

$$
Q_{b r}=m\left(\frac{2}{3}\right)^{3 / 2} \sqrt{g} B\left(H_{w}-Z_{b r}\right)^{3 / 2}
$$

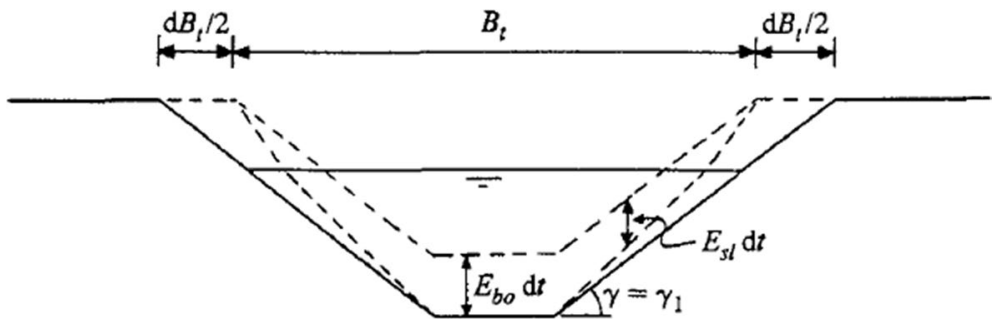

Fig. 7 Increase in $d B_{t}$ in time $d t$ of breach width $B$ near the inflow (Visser 1998a). Dashed lines indicate initial breach cross section, solid lines indicate breach cross section after time $d t$ 
in which $Q_{\mathrm{br}}$ is the flow discharge through the breach, $\left[\mathrm{m}^{3} / \mathrm{s}\right] ; m$ is the discharge coefficient $[-] ; g$ is the gravitational acceleration, $\left[\mathrm{m} / \mathrm{s}^{2}\right] ; B$ is the averaged breach width over water depth, [m]; $H_{\mathrm{w}}$ is the outer water level, i.e. water level of the river or sea, $[\mathrm{m}] ; Z_{\mathrm{br}}$ is the height of the breach bottom, [m]; and $H_{\mathrm{p}}$ is the water level in the polder behind the dike, $[\mathrm{m}]$.

The discharge coefficient $m$ is 1 in the broad-crested weir formula. In type A breaching, the berm structure is actually the breach bottom, so the height of the breach bottom $\left(Z_{\mathrm{br}}\right)$ is the height of the berm. The outer water level $\left(H_{\mathrm{w}}\right)$ is the sum of water level simulated by hydrodynamic model and the estimated wave set-up. The initial water level in the polder behind the dike $\left(H_{\mathrm{p}}\right)$ is assumed to be the bed level behind the dike. That is because the dike is assumed to breach in a short time and there is nearly no water behind the dike when the dike starts to breach. When the sea water level $H_{\mathrm{w}}$ is higher than the water level behind the dike $H_{\mathrm{p}}$, and the water level behind the dike $H_{\mathrm{p}}$ is higher than the height of the dike berm $Z_{\mathrm{b} r}$, Eq. 2 is used to calculate the breach discharge; otherwise, Eq. 3 is used. In the absence of field observations, a sensitivity analysis is conducted for breach widths of $50 \mathrm{~m}$, $100 \mathrm{~m}, 300 \mathrm{~m}, 500 \mathrm{~m}$ and 1,000 m, to see how breach width affects overland flooding.

\subsection{Overland flood model}

The overland flood model was driven by overtopping and breach discharges at the grid cells corresponding to the sea dike. Time series of discharge boundary conditions were imposed at each dike section. In the case of a dike breach, the breach discharge replaces the overtopping discharge. The model covers the mainland of Shanghai city with triangular cells of typical dimension $300 \mathrm{~m}$ (see Fig. 20 in the Appendix); and curvilinear grid cells cover the Huangpu River and other major canals. Model topography (see Fig. 21 in the Appendix) utilizes topographical data from the Shanghai Municipal Bureau of Surveying and Mapping (2010 version) (Wang et al. 2012). The overland roughness (i.e. Manning's roughness coefficient) of the urban area was assigned a uniform value of $0.06 \mathrm{sm}^{-1 / 3}$ (Bricker et al. 2015).

\section{Results and discussion}

\subsection{Results}

\subsubsection{Storm surge, storm tide and waves}

The full cascade of models (hydrodynamics, waves, overtopping, breaching, and overland flooding) was used to evaluate the impact of the hypothetical typhoons generated under past and future climate scenarios. First, the top 5 typhoon events in each climate scenario (past and future) were selected based on the ranking of surge heights and named f1, f2, f3, $\mathrm{f} 4$, f5 for the future climate scenario and p1, p2, p3, p4, p5 for the past climate scenario. $\mathrm{SS}$ ranges from $0.2 \mathrm{~m}$ to $2.7 \mathrm{~m}$ in general (see Fig. 16). The maximum surge height in the YE (range 1.5-2.7 m) is generally higher than the maximum surge height in HZB (range $0.5-1.5 \mathrm{~m}$ ), especially during the future events $\mathrm{f} 1, \mathrm{f} 2$, f4 and f5 under the RCP8.5 climate scenario. In addition, it was found that the SS height at WSK is increasingly higher in the future period than in the past period while LCG experiences the opposite trend. Recent research has showed that due to climate change, typhoons may travel further north (Altman 
et al. 2018; Baldini et al. 2016; Kossin et al. 2014; Mbengue and Schneider 2017). This may lead to increasingly extreme high SS in the YE in the future.

SS can occur at different phases of the astronomic tide. SS coincided with a high astronomical tide at WSK during typhoon Winnie in 1997 (China Marine Disaster Bulletin, 1997, http://www.soa.gov.cn). In our simulations, we force the peak surge height and peak astronomical tide levels to occur coincidentally for all the locations along the coast. Since the tide phase differs at each location, we conservatively assume the highest astronomic tide occurs at the same time of peak surge. This conservative assumption was adopted to estimate the coastal flood boundary conditions as a function of SS return period alone (Environmental Agency 2019); calculation of risk due to the independent phase correlation of the SS with the astronomical tide is beyond the scope of this paper. The downside of this assumption is over-estimation of the extreme sea level; however, in order to pursue the potential maximum risk, we rather adopt this simple linear model to predict the still water level. The astronomic tide during typhoon Winnie (from 00:00:00 15-08-1997 to 00:00:00 21-08-1997) at WSK was used as the astronomic tide for all locations along Shanghai's coastal dike during ten typhoon events. The resulting storm tide (see Fig. 17) was used for calculation of overtopping and breaching discharge in the next step. An example time series of astronomic tide, SS, wave set-up and storm tide at WSK is shown in Fig. 8. The peak height of the astronomic tide is $2.66 \mathrm{~m}$ (at 01:00:00 on a fictitious date 20-08-1997). SS reaches $2.56 \mathrm{~m}$ (at time step 76 hours) during typhoon $\mathrm{f} 1$. Wave set-up is very small, with a maximum value of $0.12 \mathrm{~m}$ in this case. Significant wave height can reach as high as nearly $5 \mathrm{~m}$ in the northern part of HZB in hypothetical typhoon $\mathrm{f} 1$. Due to the shallow water in the YE, wave height in HZB is generally higher (see Fig.18). Peak period (see Fig. 19) is $12-15 \mathrm{~s}$ in most of the past and future cases, especially along the north coast of HZB.

\subsubsection{Return period}

WSK was selected as a representative location to examine the probability of exceedance of typhoon-induced storm tide water levels. We have 111 and 103 typhoon events in the past

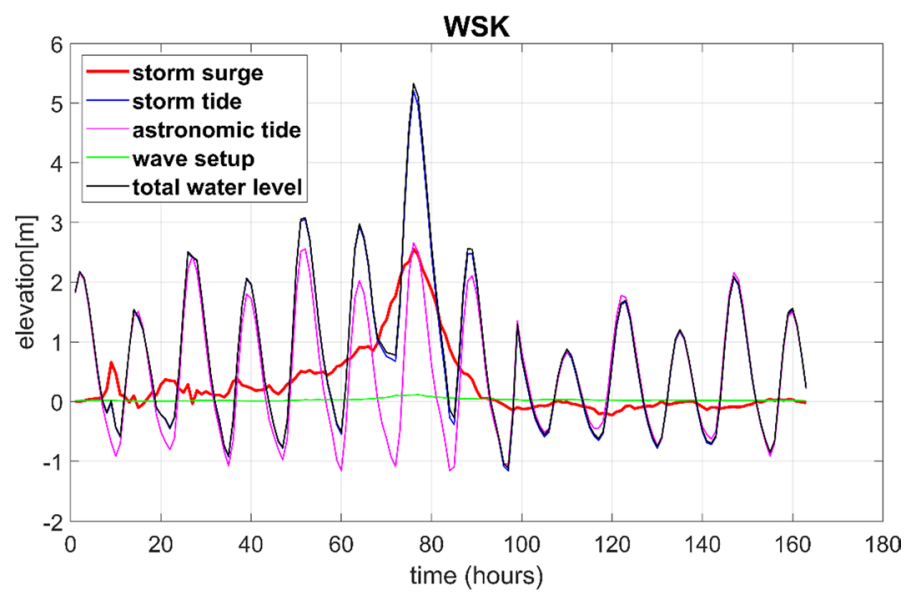

Fig. 8 Time series of storm tide, storm surge, wave set-up and astronomic tide relative to mean sea level at WSK during hypothetical typhoon $\mathrm{f1}$ 
and future periods, respectively (see Sect. 2.2). Surge height as a function of return period was calculated (via a probability distribution using the generalized extreme value (GEV) distribution) based on annual maximum surge height in the 20 years simulated for each climate scenario (past period:1981-2000; future period:2080-2099). Figure 9 shows the GEV fitting results and the range of uncertainty with 95\% confidence interval. Blue and red dots represent the annual maximum surge height from the generated surge database in the past and future periods, respectively; solid and dashed lines represent the median estimation of the GEV fitting and lower/upper bounds of estimation, respectively. The top 5 surge heights at WSK in the future (typhoons $\mathrm{f} 1, \mathrm{f} 2, \mathrm{f} 3, \mathrm{f} 4, \mathrm{f} 5$ ) are $2.56 \mathrm{~m}, 2.04 \mathrm{~m}$, $2 \mathrm{~m}, 1.92 \mathrm{~m}$ and $1.58 \mathrm{~m}$; and in the past (typhoons p1, p2, p3, p4, p5) are $1.84 \mathrm{~m}, 1.68 \mathrm{~m}$, $1.51 \mathrm{~m}, 1.32 \mathrm{~m}$ and $1.31 \mathrm{~m}$. The corresponding return periods of the future storms are 54 , 14, 13, 11 and 3 years, respectively; and of the past storms are 44, 23, 12, 5, and 4 years, respectively. These results are further applied to estimate storm tide and flood return periods. Figure 9 shows that the surge heights of the 5 future events (typhoons f1, f2, f3, f4, f5) become approximately 550, 90, 80, 60, and 15 years (respectively) if the future events are instead assigned return periods based on the GEV fit to data from the past climate scenario. This shows that at WSK, climate change leads to nonstationary SS statistics, with what used to be rare events (large return periods) becoming much more common in the future (small return periods).

\subsubsection{Overtopping and breaching}

Maximum overtopping discharge rates $\left(\mathrm{m}^{3} / \mathrm{s} / \mathrm{m}\right)$ along the coast during typhoons under past and future climates are shown in Fig.10. In order to study the individual effects of RSLR and TC climatology change on the overtopping discharge, four scenarios were formulated: (a) past climate scenario with no RSLR as a baseline scenario; (b) past climate scenario with RSLR; (c) future climate scenario with no RSLR; (d) future climate scenario with RSLR. It should be noted that the RSLR is the median estimated value of $1.19 \mathrm{~m}$ under the RCP 8.5 scenario.

Typhoon 2 produced low SS and thus low overtopping discharge along the YE under the baseline scenario, while it generated a high overtopping discharge rate (as high as

Fig. 9 Surge height at WSK as a function of return period based on GEV fitting (solid line) and the range of uncertainty with 95\% confidence intervals (dashed line)

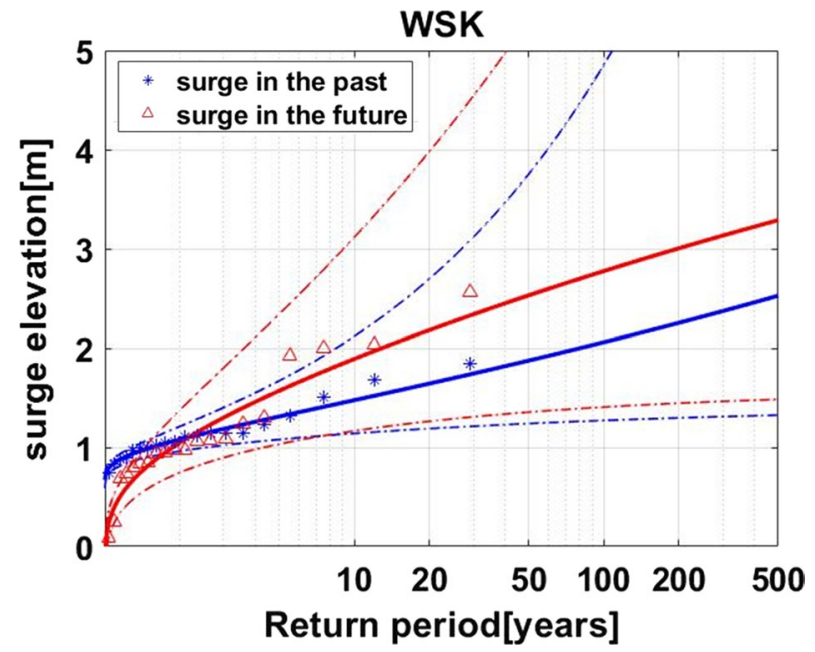



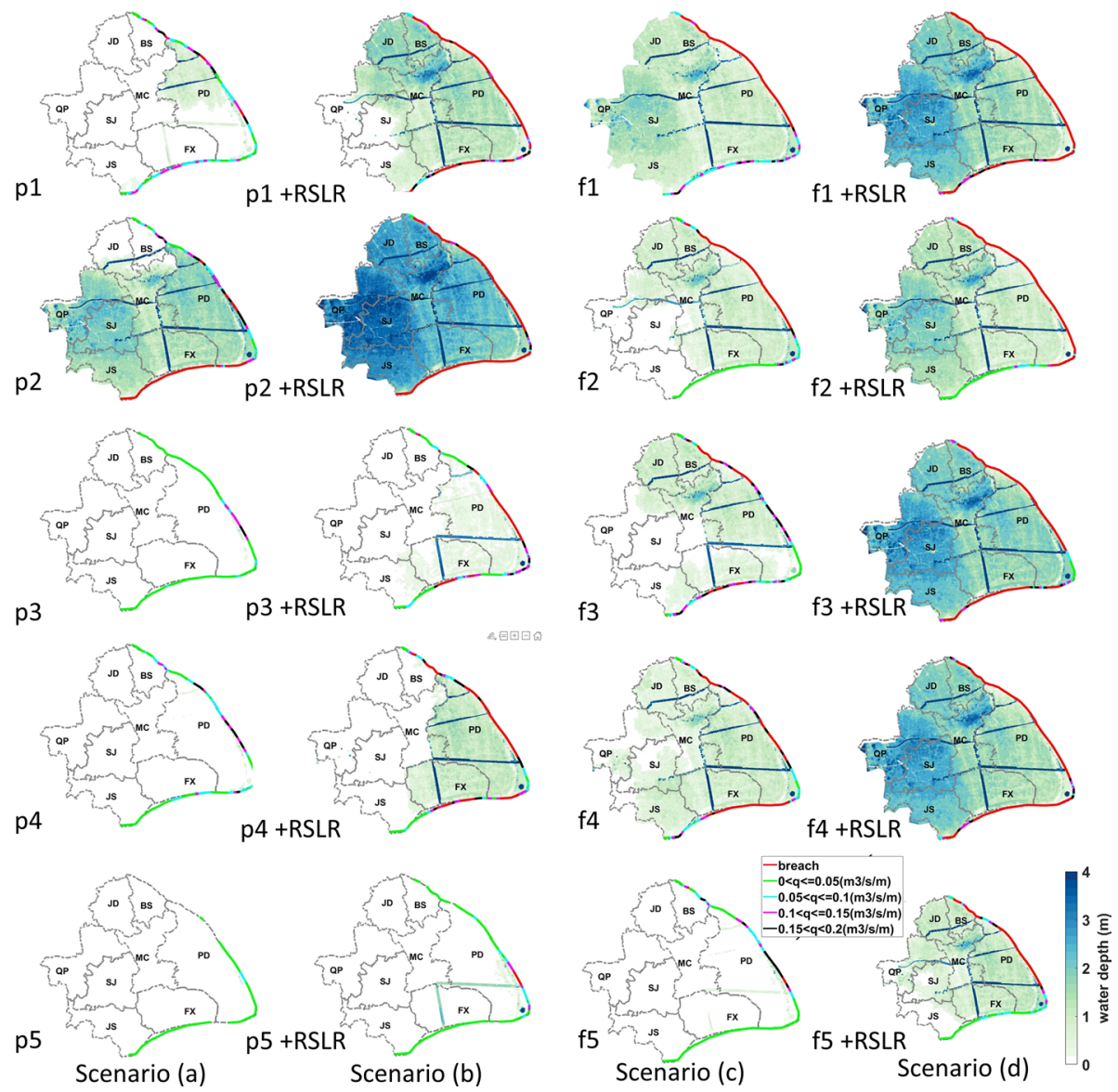

Fig. 10 Spatial extent of inundation depth due to overtopping and breaching (with breach width of $1000 \mathrm{~m}$ ) under four scenarios, and spatial distribution of breach locations (red line) and overtopping locations (green line shows an overtopping discharge rate $(q) \leq 0.05 \mathrm{~m}^{3} / \mathrm{s} / \mathrm{m}$; cyan line shows $0.05<q \leq 0.1 \mathrm{~m}^{3} / \mathrm{s} / \mathrm{m}$; magenta line shows $0.1<q \leq 0.15 \mathrm{~m}^{3} / \mathrm{s} / \mathrm{m}$; black line shows $0.15<q<0.2 \mathrm{~m}^{3} / \mathrm{s} / \mathrm{m}$ ) for 10 hypothetical typhoons

nearly $2 \mathrm{~m}^{3} / \mathrm{s} / \mathrm{m}$ ) in northern HZB (mainly in Fengxian and Jianshan districts). Typhoon $\mathrm{p} 1$ produced high discharge in the Pudong area. The other typhoons (p3, p4, p5) under the past climate generate a similar spatial distribution of overtopping as typhoon $\mathrm{p} 1$ (no more than $0.2 \mathrm{~m}^{3} / \mathrm{s} / \mathrm{m}$ ). In scenario (b), RSLR was imposed for the past typhoons in the model and the results of overtopping discharge approximately doubled compared to the baseline.

Under the future climate in scenario (c), dikes at Baoshan and Pudong North exhibited a weakness to overtopping (with a high overtopping rate of nearly $1.6 \mathrm{~m} / \mathrm{m} / \mathrm{s}$ ), especially during typhoon $\mathrm{f} 1$. On the other hand, a relatively low overtopping discharge rate was generally observed in Pudong south district (see Fig.10). Moreover, typhoon f4 generated surprisingly high overtopping discharge (up to $0.6 \mathrm{~m}^{3} / \mathrm{s} / \mathrm{m}$ ) in South Pudong and Fengxian districts. It can be seen that the overtopping discharge rate could reach up to $6 \mathrm{~m} / \mathrm{s} / \mathrm{m}$ along YE in scenario (d) during typhoon f1. In addition, if we do a cross comparison among all the scenarios, we find that the maximum overtopping discharge will increase under 
climatology change alone, but not as significantly as due to the RSLR alone, while the combined effect of climatology change and RSLR leads to $\sim 10$ times more discharge than baseline scenario.

Furthermore, Fig. 10 indicates plausible breach and overtopping locations. Breaching occurred during two cases (out of five) in past climate scenario (a), in which one of the two (typhoon p1) causes limited breach in Baoshan and Pudong. In the future climate scenario (d), all five typhoons cause large breach sections (see the red lines in Fig.10). Typhoons f1, $\mathrm{f} 2, \mathrm{f} 3, \mathrm{f} 4$ breach over $60 \%$ of the dikes, while the remainder of the dikes were overtopped without breaching.

In order to quantitatively study the relative contribution of RSLR and TC climatology change to inundation, we calculate the difference in breach length when the effects of RSLR, TC climatology change, and their combination were considered in the scenarios. Differences in breach lengths between scenarios were normalized as $\Delta_{\mathrm{TC}}, \Delta_{\mathrm{rslr}}, \Delta_{\text {combined }}$, in Eq. (4). In Eq. (5) and Eq. (6), $\mu$ is a measure of the relative contribution of each individual factor, which is calculated by dividing $\Delta_{\text {combined }}$ by each individual difference.

$$
\begin{gathered}
\Delta_{\mathrm{TC}}=\frac{L_{\mathrm{TC}}-L_{\text {baseline }}}{L_{\text {baseline }}} ; \Delta_{\mathrm{rslr}}=\frac{L_{\mathrm{rslr}}-L_{\text {baseline }}}{L_{\text {baseline }}} ; \Delta_{\text {combined }}=\frac{L_{\text {combined }}-L_{\text {baseline }}}{L_{\text {baseline }}} \\
\mu_{\mathrm{TC}}=\frac{\Delta_{\mathrm{TC}}}{\Delta_{\text {combined }}} \times 100 \% \\
\mu_{\mathrm{rslr}}=\frac{\Delta_{\text {rslr }}}{\Delta_{\text {combined }}} \times 100 \%
\end{gathered}
$$

Here: $L_{\text {baseline }}$-breach length in scenario (a); $L_{\mathrm{rslr}} L_{\mathrm{TC}}, L_{\text {combined }}{ }^{-}$breach length in scenarios (b), (c) and (d), respectively; $\Delta$-difference in each individual scenario's breach length compares to baseline; $\mu$-relative contribution of TC climatology change vs. RSLR.

Figure 11 shows the percentage of breach and overtopping lengths for typhoon events under the four scenarios. RSLR ranging between $1.05 \mathrm{~m}$ and $1.32 \mathrm{~m}$ was taken into account in scenarios (b) and (d). The longer the red bars in Fig. 11 are, the more breaching exists. Figure 11 shows that RSLR is the dominating factor, which accounts for $50 \%-70 \%$ of the increase in breach length compared to the baseline scenario, while TC climatology change exhibits a smaller relative contribution of around $30 \%-40 \%$.

\subsubsection{Flood maps}

Flooding due to overtopping alone is very limited in terms of inundation extent (which is represented by the flooded area divided by the whole area of mainland Shanghai) under typhoons p3, p4, p5 in scenario (a). As seen from Fig. 10, dike sections with overtopping discharge rate greater than $0.05 \mathrm{~m}^{3} / \mathrm{s} / \mathrm{m}$ are mainly in Pudong district in scenario (a). Accounting for time variation of the astronomical tide, SS, and wave conditions (see Fig. 8), overtopping discharge varied based on the variation of water level in front of dike. For each case, overtopping lasted only a few hours, while SS coincided with the high astronomical tide.

A sensitivity analysis of the effect of breach width on the flooding characteristics was conducted, with results as shown in Fig. 22. Breach widths of $50 \mathrm{~m}, 100 \mathrm{~m}, 300 \mathrm{~m}, 500 \mathrm{~m}$ and $1000 \mathrm{~m}$ were selected based on (1) an empirical model to predict the final breach width 

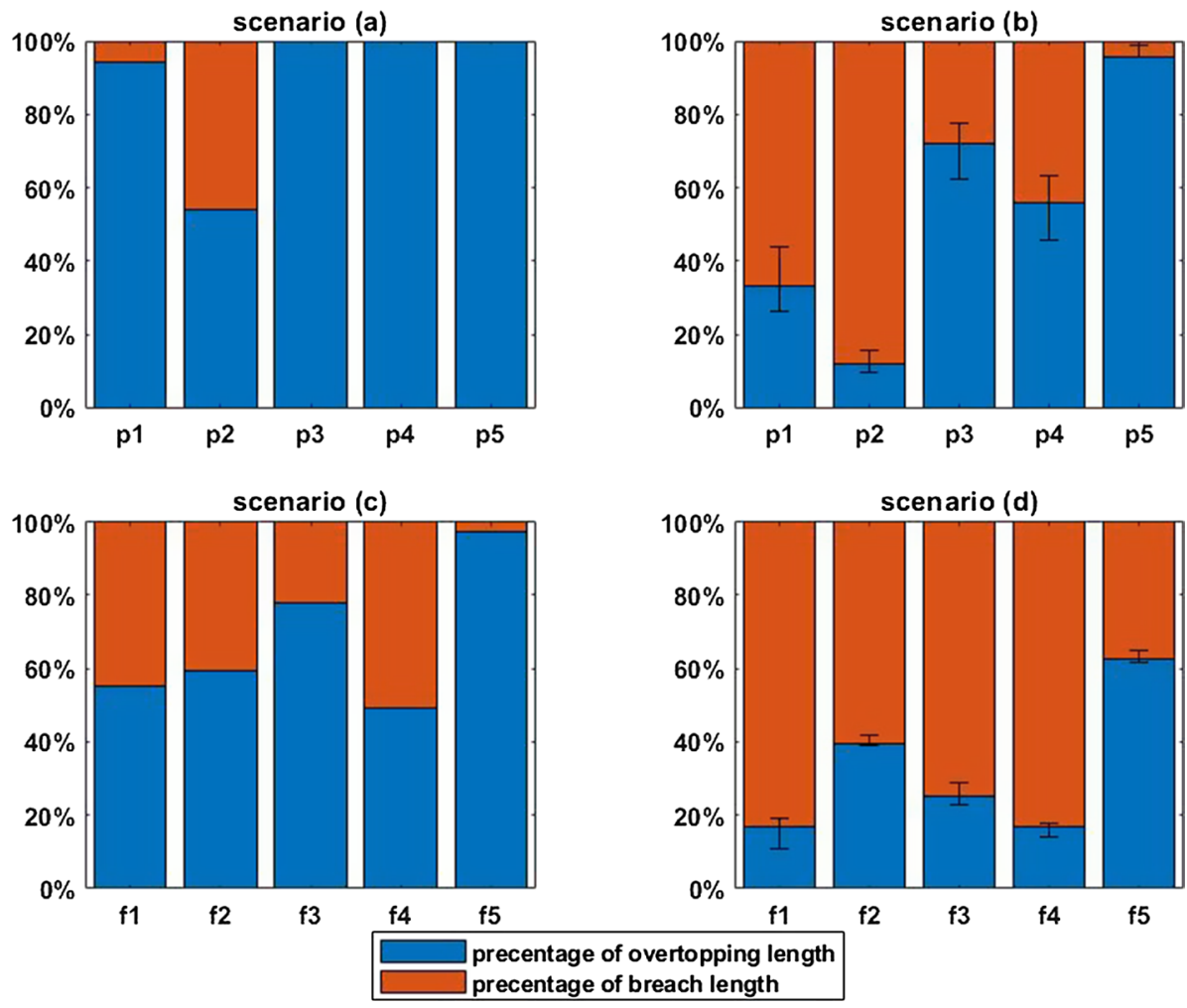

Fig. 11 Percentage of breach and overtopping length under the four scenarios. The red/blue boundary on each bar indicates the median estimation of RSLR in scenarios (b) and (d), with lower and upper bounds represented by whiskers

in the Netherlands (Verheij et al. 2009) and (2) the observed record of breaches in the Zhaoyuan dike (max. breach width $530 \mathrm{~m}$ ) and Paizhou dike (max. breach width $760 \mathrm{~m}$ ) along the Yangtze River during a massive flood in 1998 (Verheij et al. 2009). Obviously, a breach width of $1000 \mathrm{~m}$ explicitly increases flood characteristics, producing extremely high average water depth (more than $7 \mathrm{~m}$ ) and inundating all of Shanghai in scenario $(\mathrm{d})$, for instance typhoon f1 (see Fig. 10). Susceptible areas deeply flooded in typhoons p2 in scenario (b) and f1,f3,f4 in scenario (d) are low-lying areas (see MC-main city; QP-Qingpu district; SJ-Songjiang district in Fig. 10); these areas are overwhelmed by the flood water from dike breaches along the Shanghai coast.

\subsection{Discussion}

\subsubsection{Model coupling}

This study computed inundation characteristics using off-line coupled models starting from a hydrodynamic model and wave model to compute hydraulic loads on discretized dike sections, and then the overtopping/breach discharge calculated by empirical models was provided as input boundary conditions to drive the flow routing in the overland flood 
model. Dike breaching is triggered in a deterministic way by an estimated tolerable limit of overtopping discharge $\left(0.2 \mathrm{~m}^{3} / \mathrm{s} / \mathrm{m}\right)$ in the system and an instantaneous collapse associated with a maximum breach width was assumed. Since the breach growth process was ignored, the breach outflow discharge was overestimated and led to an unrealistically large inundation depth and inundation extent in general. Therefore, time-dependent breach modelling is recommended. Also, a deterministic threshold was used to determine the point of breaching. However, probabilistic analysis of dike failure as parameterized by fragility curves (failure probability as a function of hydraulic load) would better quantify the uncertainty in failure and breaching.

\subsubsection{Coastal flood hazard}

We define coastal flood hazard as a function of flood water volume and the corresponding return period of the flood event. The return period of a typhoon is assumed to be the return period of the maximum water level generated by the typhoon in the past and future periods at WSK. Figure 12 shows flood water volume (the average value for five different breach width scenarios) decreases as the probability of exceedance of a flood event (the inverse of the return period of flood event) increases. As seen from Fig. 10, breaching mainly occurred on the dikes along the YE during most typhoon events, and the TC climatology change and RSLR in scenario (d) led to breaches along HZB during typhoons f1, f3, $\mathrm{f} 4$, which contributes to a large degree to the flood water volume. Even though the water level is not very high at WSK during typhoon p2 (with a small return period of $\sim 30$ years based on water level at WSK) this typhoon brings extremely high overtopping and potential breaches along HZB (in Fengxian and Jinshan Districts) especially in scenario (b). In addition, it can be seen that the flood hazard will largely increase in the future, in which all the top five typhoons under the future climate scenarios (c) and (d) have plausible dike breaches and result in large flood water volume while only two out of the top five typhoons

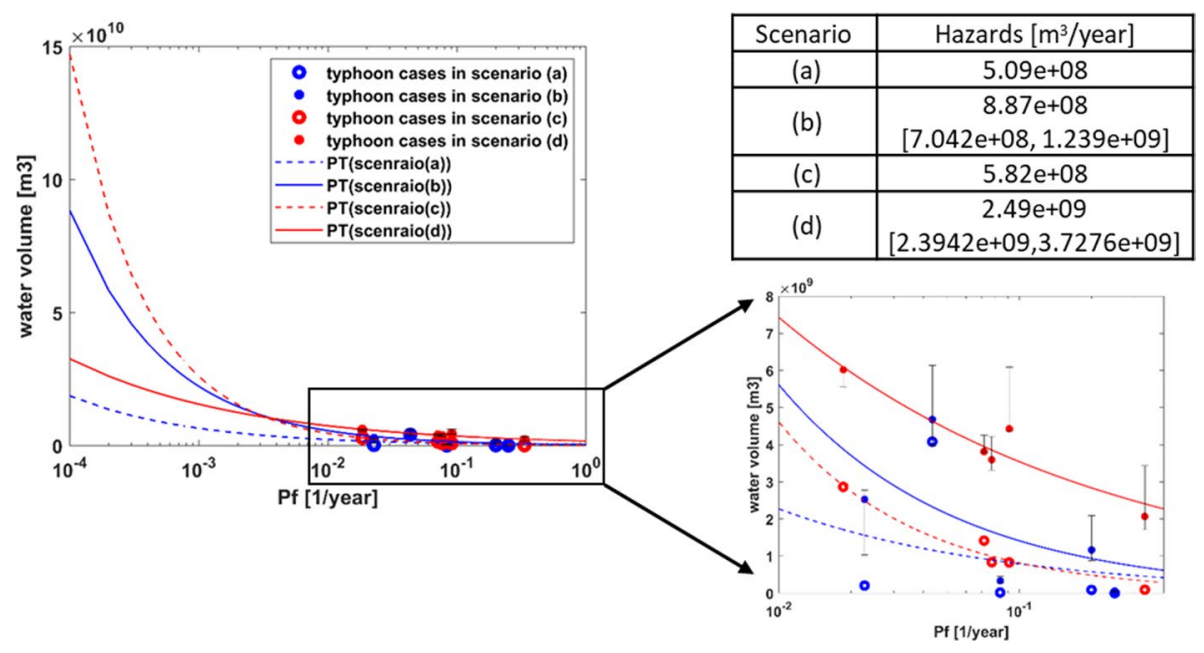

Fig. 12 Flood inundation volume corresponding to the return periods of each flood event for different scenarios. X-axis shows the probability exceedance of the flood event; y-axis shows the average flood water volume under all breach width scenarios; median estimation with lower and upper bounds of SLR for scenarios (b) and (d); PT-power fitting 
in the past climate scenario led to dike breaches. In order to quantify the flood hazards under different scenarios, power fit curves were used and the area under each curve was calculated by integration (see Fig. 12). This area is regarded as the inundation volume hazard $\left(\mathrm{m}^{3} /\right.$ year) under each scenario. The table in Fig. 12 shows that flood hazard in scenario (d) is greater than the hazard in scenario (b), which is greater than the hazard in scenario (c), which is greater than the hazard in scenario (a), even accounting for the uncertainty of RSLR. This result is in line with the study on the individual effects of RSLR and TC climatology change on future coastal flooding using the indicator of 'breach length' of sea dikes in Sect. 4.1.3, in which the lower and upper bound estimates of RSLR were taken into account for scenarios (b) and (d).

\subsubsection{Limitations of approach}

Although the presented results appear to be plausible and are accompanied by uncertainty estimations, it is clear that such comprehensive approaches have their limitations. The developed methodology considers the parameter uncertainty only, i.e. the relative variation of RSLR. The lower and upper boundaries of RSLR were taken into account in the calculation process of still water level, overtopping, breaching, and consequently flood hazard. However, uncertainties of other parameters in the overtopping and breach models are not taken into account. These uncertainties may stem from measurement errors or errors reported in the literature. For example, the crest height, toe of the dike, the berm height and crown wall, etc., were measured during a field investigation, but where sea dike access was impossible or unsafe, elevations were instead based on rough estimation. In addition, other stochastic parameters used mean or default values only. However, their uncertainties can be modelled by using statistical distributions. Another source of uncertainty is from the model itself. The overtopping and breaching models are empirical and theoretical relationships describing the physical processes. A historical typhoon event (Typhoon Winnie) was used to validate the overtopping results by a comparison of the reported locations of dike breach with the calculated overtopping discharge rate. The assumption of dike breach when overtopping discharge exceeds a threshold discharge rate has particularly large impacts on the resulting flood, but data on this threshold discharge are scarce and highly uncertain. Additional uncertainty is caused by the lack of calibration and validation of the breaching model due to insufficient data. However, sensitivity runs with different breach widths indicate that the uncertainty in the maximum water depth, flood extent and water volume is dominated by ultimate breach width (see Fig. 22). These uncertainties have to be taken into account when using the derived flood maps for future flood management planning. It is thus recommended to use the maps mainly for the identification of the most vulnerable areas, and to use the inundation depths with caution. 


\section{Conclusions}

An integrated framework of coastal flood modelling for areas with coastal dikes considering the combined effects of SLR, land subsidence and increasing TC intensity was developed and implemented for the Shanghai coast. This integrated model is developed for prediction of flood inundation due to failure of dikes (overtopping and breaching) in the coastal city. Firstly, it proved that the developed SS and wave model can predict realistic results during typhoons in this region. The developed model can be used to predict SS and wave heights under any typhoon case (synthetic typhoons or best tracks of future typhoons). It can provide information for flood early warning centres or emergency management centres. Secondly, the methodology can also be applied to other cities in the world to examine coastal flooding due to failure of dikes (overtopping/breaching) instead assuming the whole dike would fail or be breached as in the conventional method. Therefore, this framework can contribute to an enhanced support for coastal managers to avoid or mitigate the effects of major disasters.

Unsurprisingly, we find that future TC climatology change causes a reduction in the return period of SS at WSK, due to the more common occurrence of intense typhoons (Fig. 9). Together with future RSLR, this increases the flood hazard to which Shanghai will be exposed in the future (Fig. 12). The continued application of this framework explored the effects of RSLR and the change of climatology on coastal flood hazards in Shanghai. It was found that RSLR is likely to have larger effect (50\%-70\%) than TC climatology change (30-40\%) on dike breach length along the Shanghai coast (Fig. 11). This provides insights for decision makers on the strategic planning of coastal flood prevention in the future, specifically, to plan the maintenance of coastal sea dikes and other measures to address RSLR. In addition, damage assessors and flood risk managers (the downstream partners of this project) can further identify risky areas based on the flood hazard maps (Fig. 10).

Finally, we acknowledge that precipitation during the typhoons was not taken into account in this study. Knutson et al. (2010) pointed out precipitation intensity is projected to increase on the order of $20 \%$ within $100 \mathrm{~km}$ of the storm center due to climate change. In addition, it was found that the translation speed of TCs has decreased $10 \%$ globally since 1949, which may lead to an increase in rain intensity (Hall and Kossin 2019; Kossin 2018). Therefore, further work must look at the compound effects of SS and precipitation induced by typhoons on the change of flood patterns due to climate change in deltaic areas.

\section{Appendix 1}

See Figs. 13-22. 

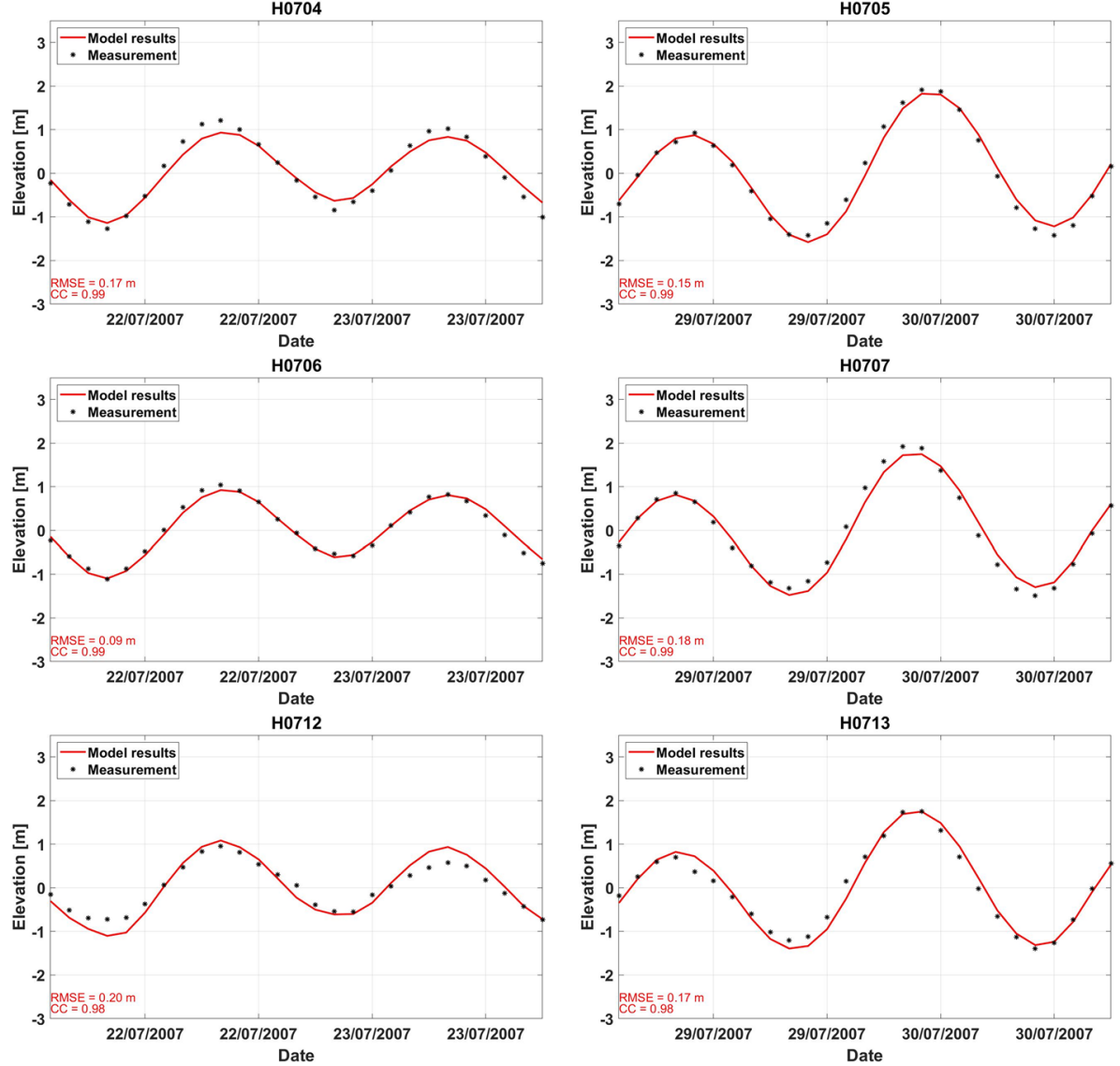

Fig. 13 Model results of tide compared to measured tide level (red lines indicate the model results, black points indicate measurements). Vertical datum is mean sea level 

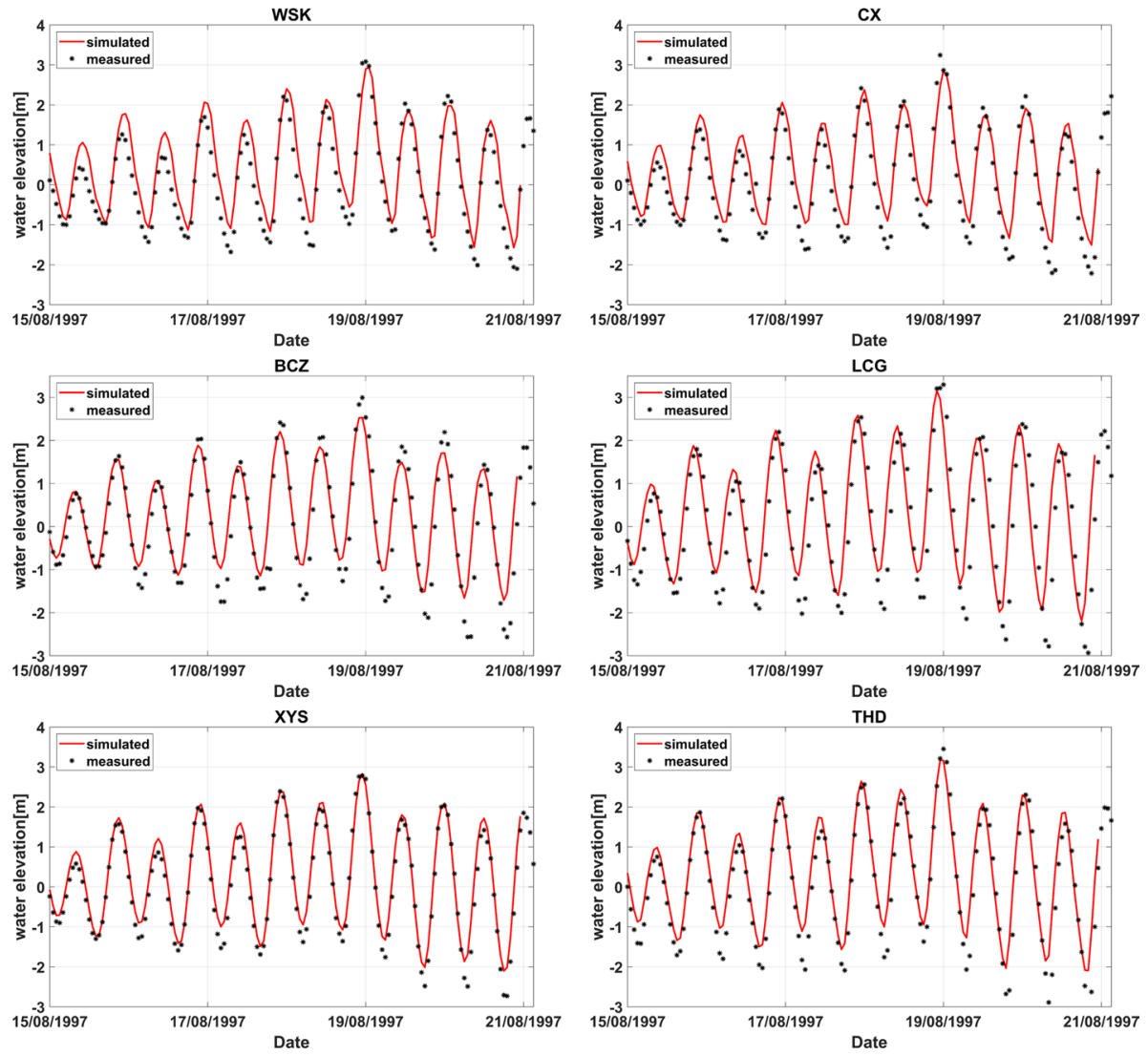

Fig. 14 Model results of storm tide compared to measured water level (red lines indicate the model results, black points indicate measurements). Vertical datum is mean sea level
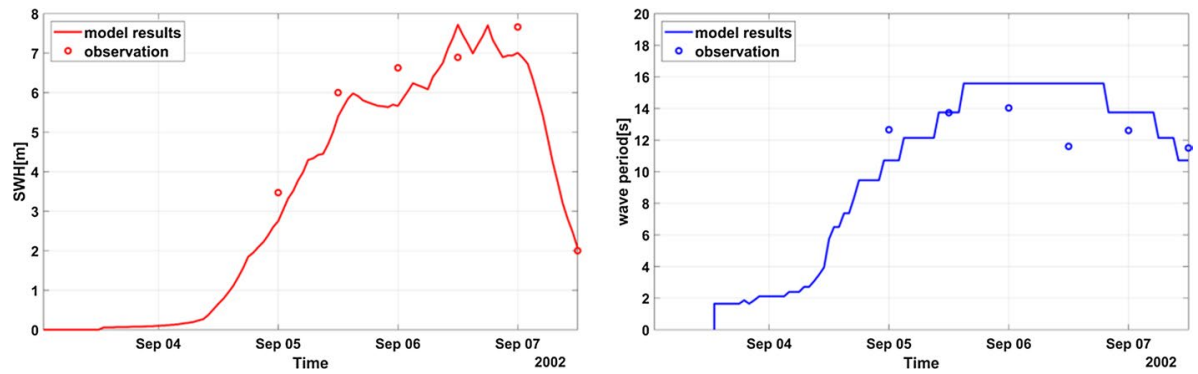

Fig. 15 Measured vs. modeled significant wave height (SWH) and peak wave period at buoy station $\left(123.59^{\circ} \mathrm{E}, 29.29^{\circ} \mathrm{N}\right)$ during Typhoon Shikula in 2002 

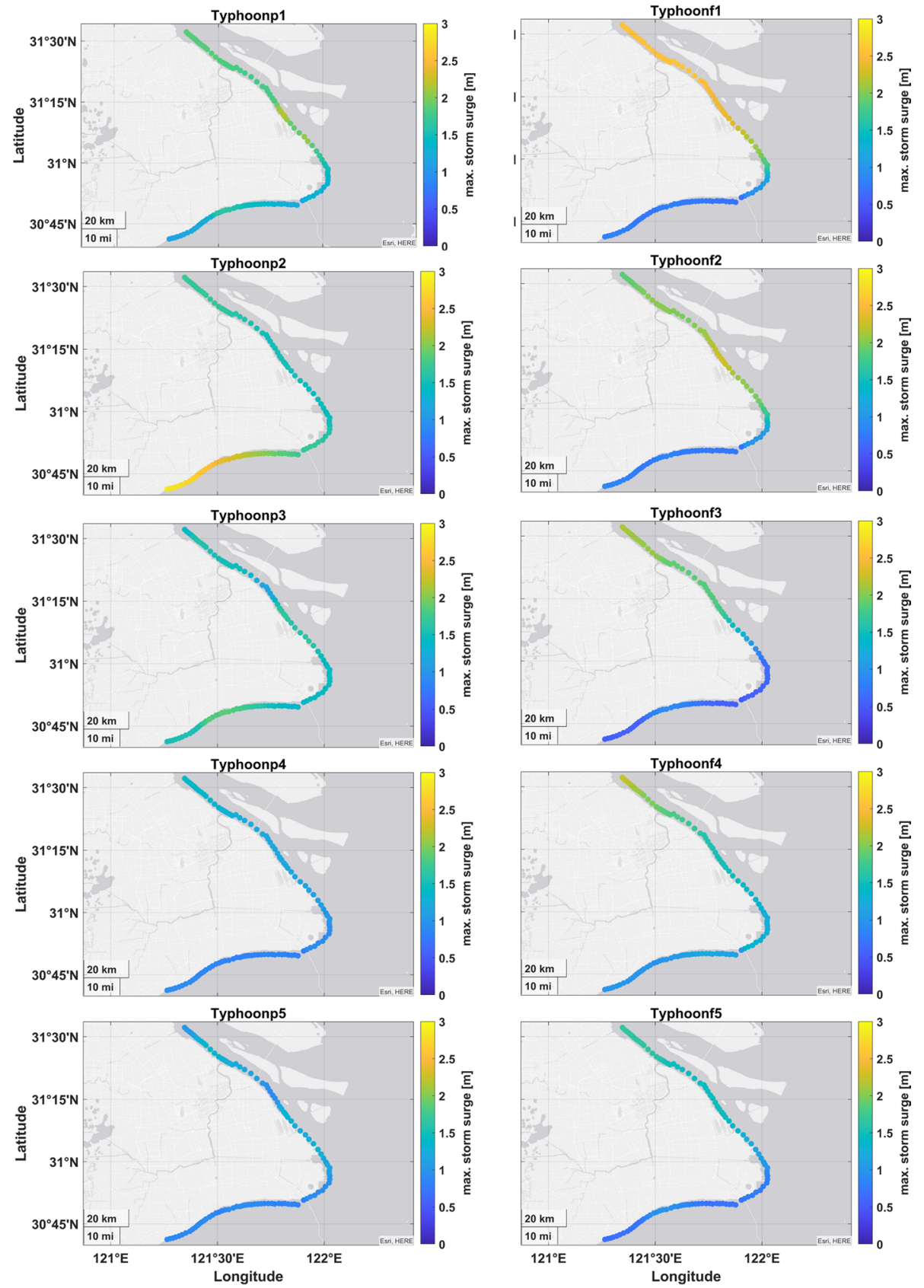

(a) past climate (1981-2000)

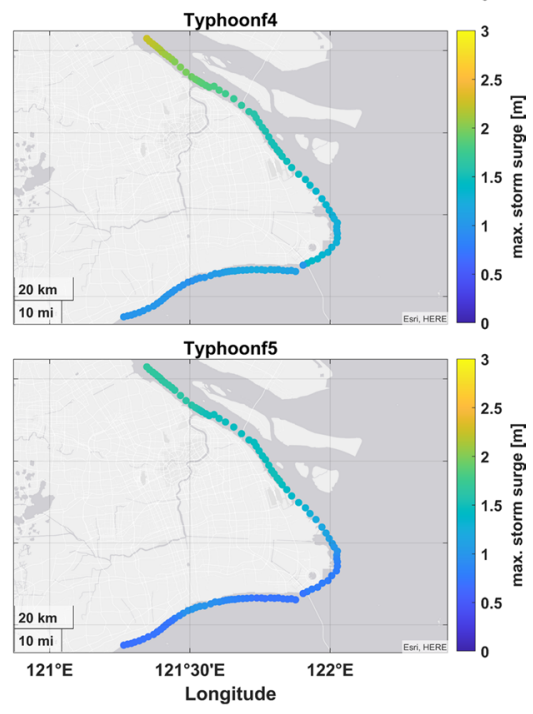

(b) future climate (2080-2099)

Fig. 16 Maximum storm surge for ten typhoon cases along the coast of Shanghai (relative to m.s.1) a past climate (1981-2000) and b future climate (2080-2099) 


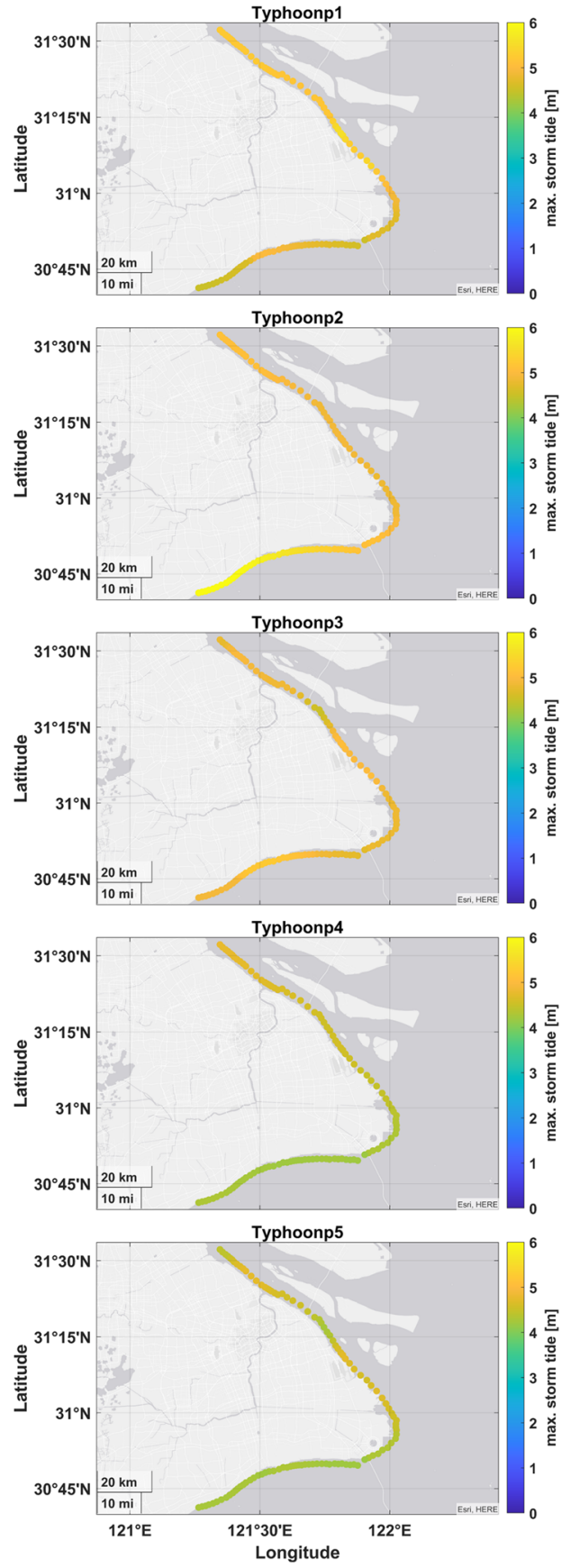

(a) past climate (1981-2000)

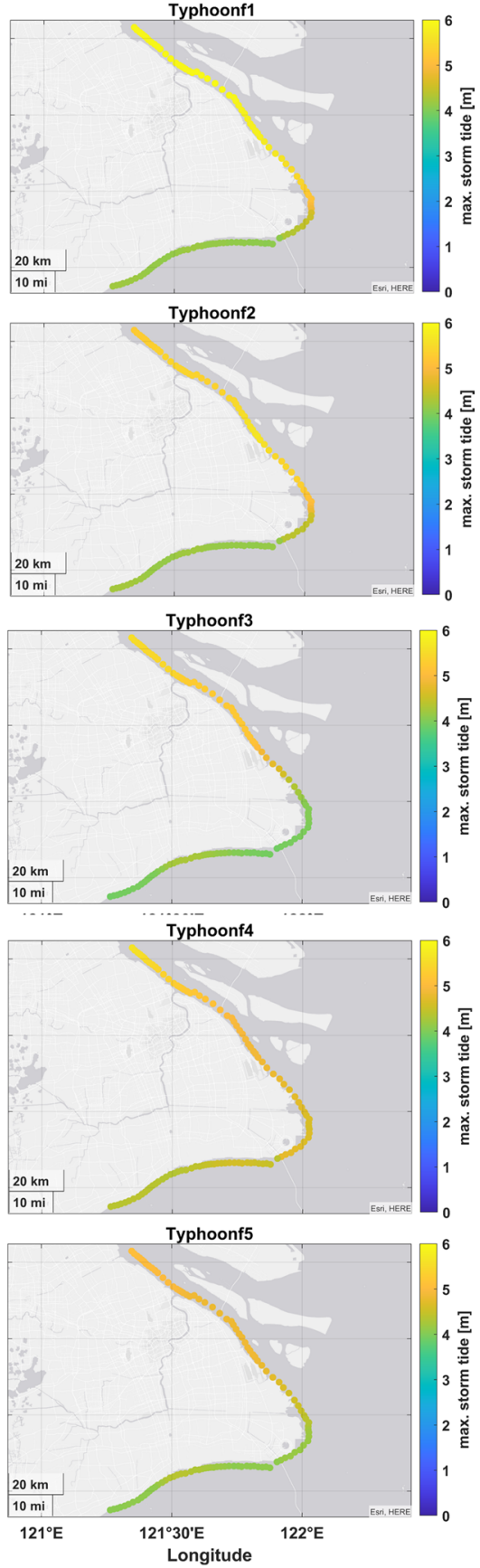

(b) future climate (2080-2099)

Fig. 17 Maximum storm tide for ten typhoon cases along the coast of Shanghai (relative to m.s.l) a past climate (1981-2000) and b future climate (2080-2099) 

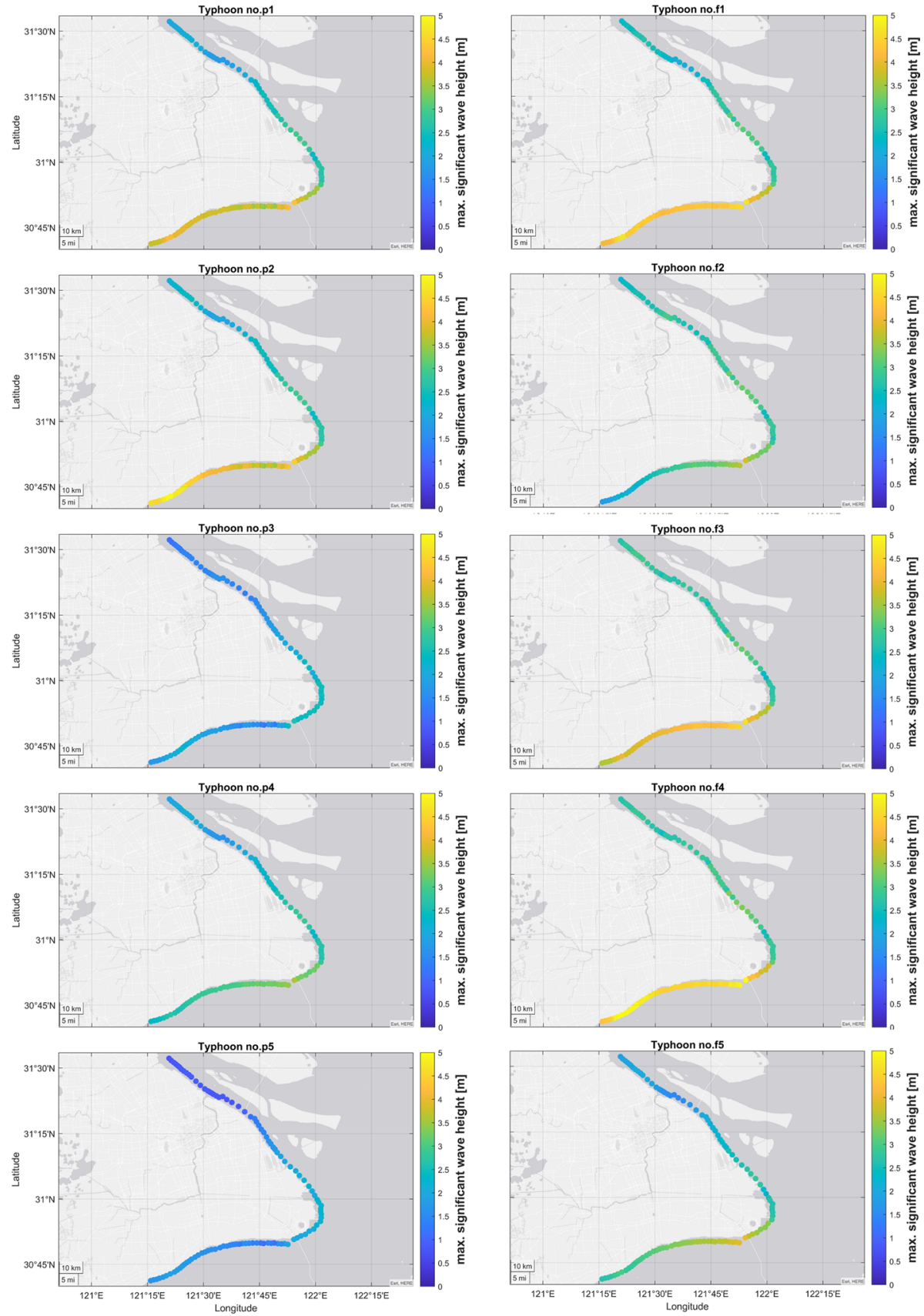

(a) past climate (1981-2000)

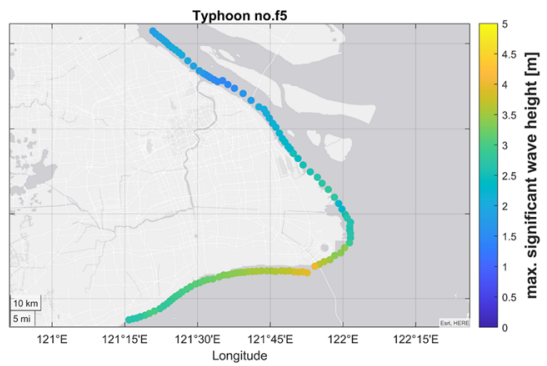

(b) future climate (2080-2099)

Fig. 18 Maximum significant wave height for ten typhoon cases along the coast of Shanghai a past climate (1981-2000) and b future climate (2080-2099) 

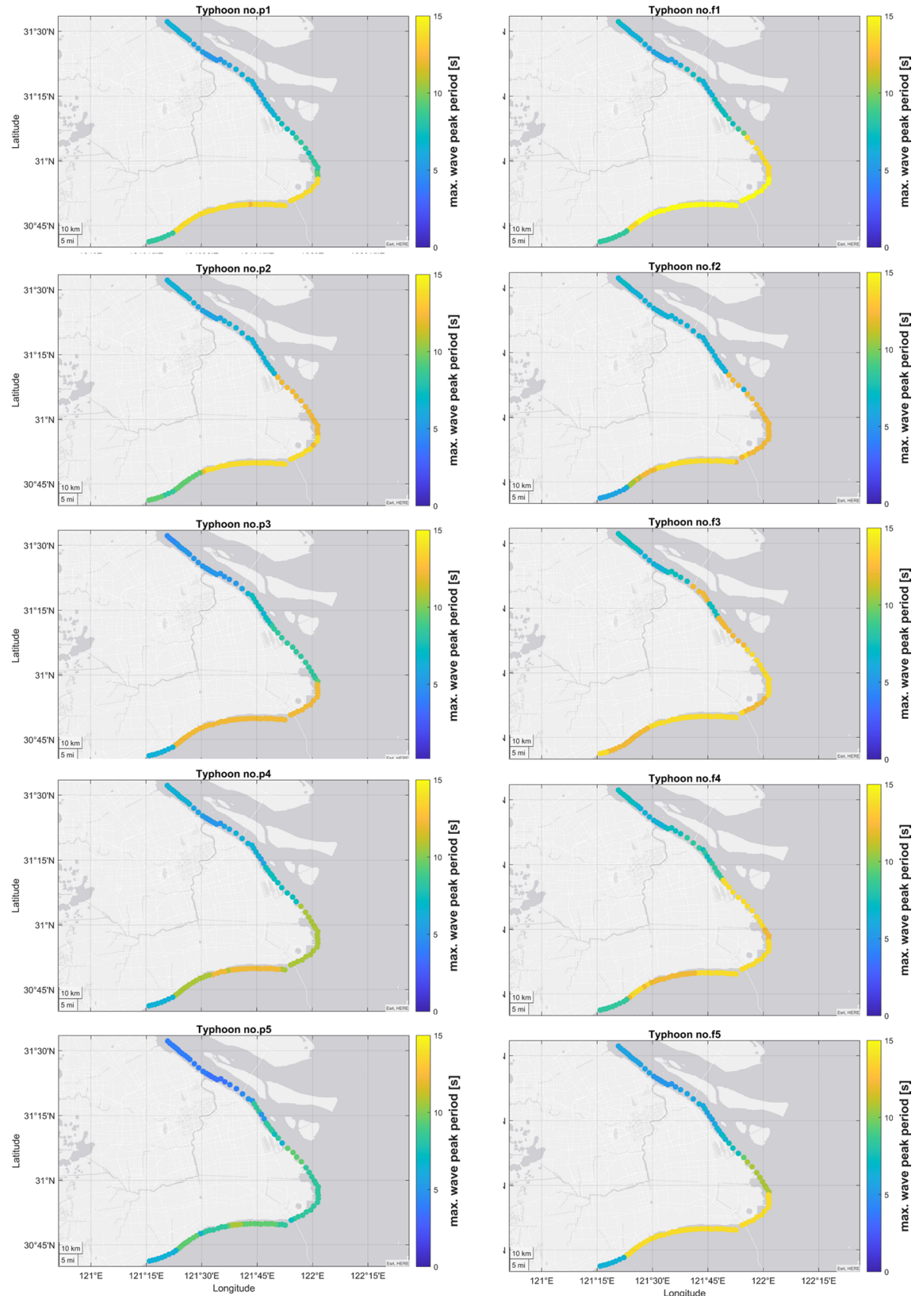

(a) past climate (1981-2000)

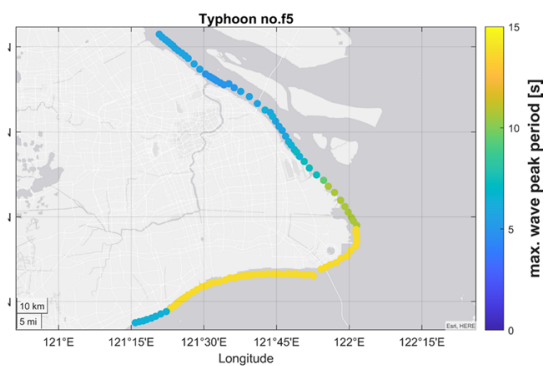

(b) future climate (2080-2099)

Fig. 19 Maximum wave peak period for ten typhoon cases along the coast of Shanghai a past climate (1981-2000) and b future climate (2080-2099) 


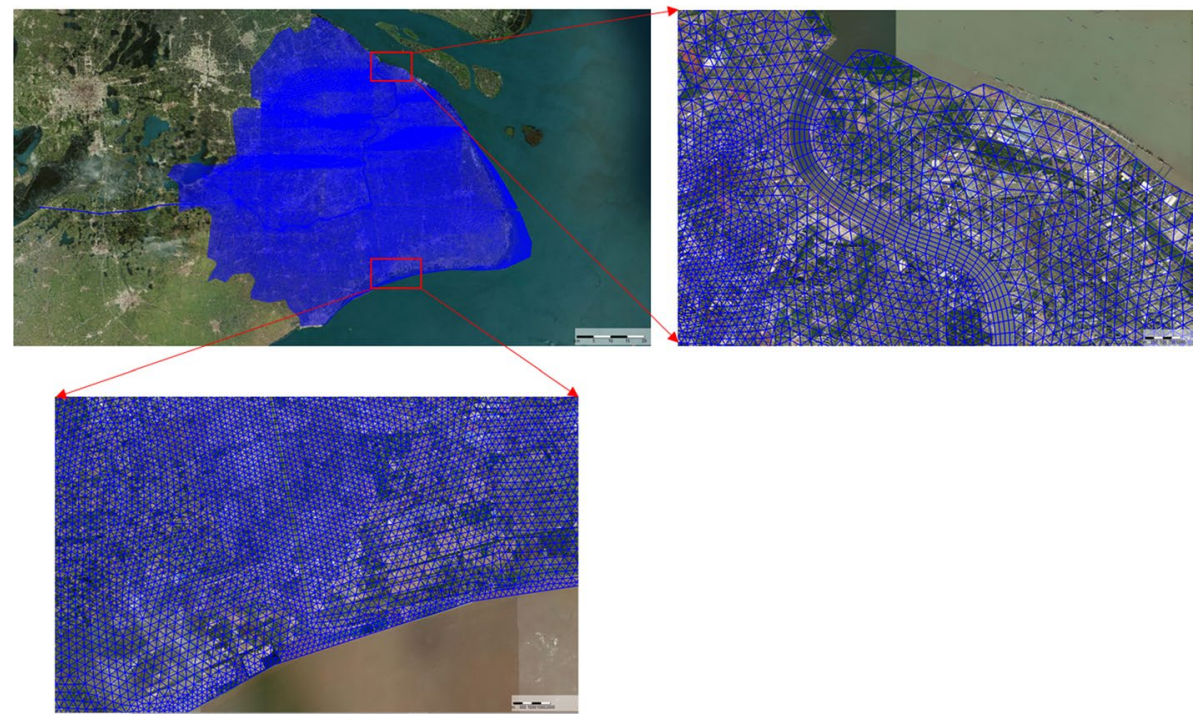

Fig. 20 Domain of overland flood model with triangular and curvilinear grid cells

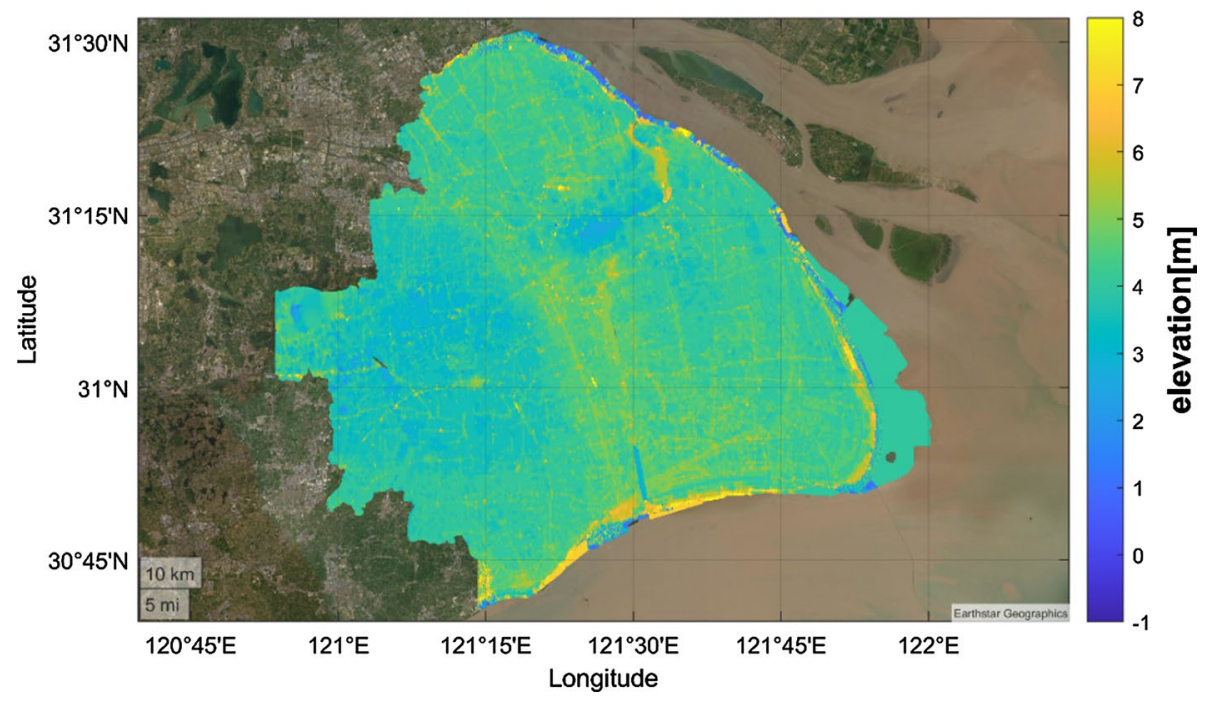

Fig. 21 Topography (relative to Wusong datum) of the overland flow model 

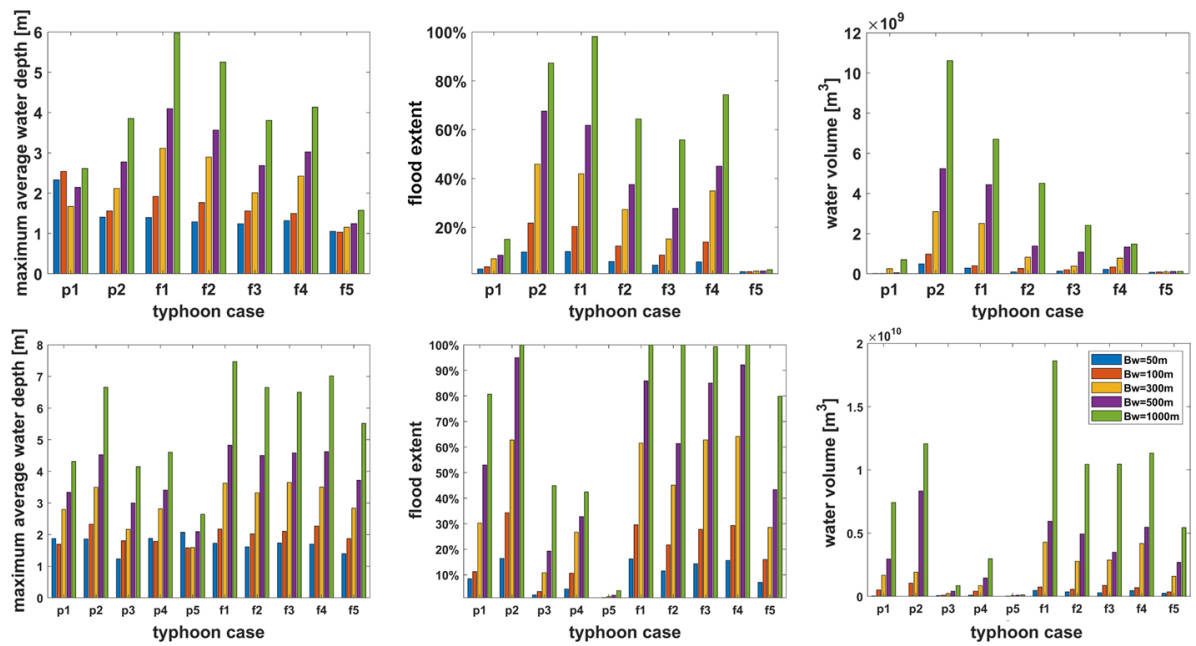

Fig. 22 Comparison of flood characteristics due to dike breach in terms of maximum average water depth $(\mathrm{m})$, flood extent and water volume $\left(\mathrm{m}^{3}\right)$ under different breach widths $(50 \mathrm{~m}, 100 \mathrm{~m}, 300 \mathrm{~m}, 500 \mathrm{~m}, 1000 \mathrm{~m})$. The first row of results for scenarios (a) and (c), the second row of results is for scenarios (b) and (d)

Acknowledgements We show our gratitude to Prof. Jiahong Wen from Shanghai Normal University and Dr. Xingcheng Liu from Shanghai Water Engineering Design and Research Institute CO., LTD (SWEDRI) for their support of the sea-dike field survey in 2019. We also would like to thank Eric de Goede and Herman Kernkamp at Deltares for providing valuable comments on an early version of this manuscript.

Authors' contributions JB, QK, ZT, LS and SJ conceived the study. QK, JY and JB drafted the manuscript JY conducted the field work. NS, EB, GD and SW contributed to the metrological forcing. QK, QY and JY were responsible for hydrodynamic modelling and wave modelling. PV was responsible for dike breach modelling. QK performed flood inundation modelling. All authors commented on the manuscript.

Funding The authors would like to thank the sponsors of this work: the Netherlands Organization for Scientific Research (NWO) (Grant no. ALWSD.2016.007), the National Natural Science Foundation of China (Grant number: 51761135024), and the Engineering and Physical Sciences Research Council of the UK (Grant Nos. R034214/1).

Availability of data and material Datasets for the sea dike information are available from the first author upon reasonable request.

Code availability Input files for the numerical simulations are available from the first author upon reasonable request.

\section{Declarations}

Conflicts of interests The authors declare that they have no known competing financial interests or personal relationships that could have appeared to influence the work reported in this paper.

Ethical approval All authors certify that they have no affiliations with or involvement in any organization or entity with any financial interest or non-financial interest in the subject matter or materials discussed in this manuscript.

Consent to participate All authors consent to participate in the work done. Other than the authors, there are no participants.

Consent for publication All authors consent to publication of this work. 
Open Access This article is licensed under a Creative Commons Attribution 4.0 International License, which permits use, sharing, adaptation, distribution and reproduction in any medium or format, as long as you give appropriate credit to the original author(s) and the source, provide a link to the Creative Commons licence, and indicate if changes were made. The images or other third party material in this article are included in the article's Creative Commons licence, unless indicated otherwise in a credit line to the material. If material is not included in the article's Creative Commons licence and your intended use is not permitted by statutory regulation or exceeds the permitted use, you will need to obtain permission directly from the copyright holder. To view a copy of this licence, visit http://creativecommons.org/licenses/by/4.0/.

\section{References}

Acosta LA, Eugenio EA, Macandog PBM, Macandog DBM, Lin EKH, Abucay ER, Cura AL, Primavera MG (2016) Loss and damage from typhoon-induced floods and landslides in the Philippines: community perceptions on climate impacts and adaptation options. Int J Glob Warm 9(1):33. https://doi.org/ 10.1504/IJGW.2016.074307

Ali A (1999) Climate change impacts and adaptation assessment in Bangladesh. Clim Res 12:109-116

Altman J, Ukhvatkina ON, Omelko AM, Macek M, Plener T, Pejcha V, Cerny T, Petrik P, Srutek M, Song J-S, Zhmerenetsky AA, Vozmishcheva AS, Krestov PV, Petrenko TY, Treydte K, Dolezal J (2018) Poleward migration of the destructive effects of tropical cyclones during the 20th century. Proc Natl Acad Sci 115(45):11543-11548. https://doi.org/10.1073/pnas.1808979115

Baldini LM, Baldini JUL, McElwaine JN, Frappier AB, Asmerom Y, Liu KB, Prufer KM, Ridley HE, Polyak V, Kennett DJ, MacPherson CG, Aquino VV, Awe J, Breitenbach SFM (2016) Persistent northward North Atlantic tropical cyclone track migration over the past five centuries. Sci Rep 6(May):1-8. https://doi.org/10.1038/srep37522

Balica SF, Wright NG, van der Meulen F (2012) A flood vulnerability index for coastal cities and its use in assessing climate change impacts. Nat Hazards 64(1):73-105. https://doi.org/10.1007/ s11069-012-0234-1

Bhatia K, Vecchi G, Murakami H, Underwood S, Kossin J (2018) Projected response of tropical cyclone intensity and intensification in a global climate model. J Clim 31(20):8281-8303. https://doi.org/10. 1175/JCLI-D-17-0898.1

Bhatia KT, Vecchi GA, Knutson TR, Murakami H, Kossin J, Dixon KW, Whitlock CE (2019) Recent increases in tropical cyclone intensification rates. Nat Commun 10(1):1-9. https://doi.org/10.1038/ s41467-019-08471-z

Bricker JD, Gibson S, Takagi H, Imamura F (2015) On the need for larger Manning's roughness coefficients in depth-integrated tsunami inundation models. Coast Eng J 57(02):1550005

Bush M, Allen T, Bain C, Boutle I, Edwards J, Finnenkoetter A, Franklin C, Hanley K, Lean H, Lock A, Manners J, Mittermaier M, Morcrette C, North R, Petch J, Short C, Vosper S, Walters D, Webster S, Weeks M, Wilkinson J, Wood N, Zerroukat M (2020) The first Met office unified model-JULES regional atmosphere and land configuration, RAL1. Geosci Model Dev 13(4):1999-2029. https://doi. org/10.5194/gmd-13-1999-2020

Chu D, Zhang J, Wu Y, Jiao X, Qian S (2019) Sensitivities of modelling storm surge to bottom friction, wind drag coefficient, and meteorological product in the East China Sea. Estuar Coast Shelf Sci 231:106460. https://doi.org/10.1016/j.ecss.2019.106460

Collins WJ, Bellouin N, Doutriaux-Boucher M, Gedney N, Halloran P, Hinton T, Hughes J, Jones CD, Joshi M, Liddicoat S, Martin G, O’Connor F, Rae J, Senior C, Sitch S, Totterdell I, Wiltshire A, Woodward S (2011) Development and evaluation of an earth-system model - HadGEM2. Geosci Model Dev 4(4):1051-1075. https://doi.org/10.5194/gmd-4-1051-2011

De Goede ED (2020) Historical overview of 2D and 3D hydrodynamic modelling of shallow water flows in the Netherlands. Ocean Dyn 70(4):521-539. https://doi.org/10.1007/s10236-019-01336-5

Deltares: D-Flow Flexible Mesh. Computational Cores and User Interface. User Manual. Released for Delft3D Flexible Mesh Suite 2020. Version 0.9.1 SVN Revision 68462. 25 September 2020

Deltares: WES-Wind Enhance Scheme for cyclone modelling - User Manual, Version:3.01. SVN Revision:68491. 2021

Du S, Scussolini P, Ward PJ, Zhang M, Wen J, Wang L, Koks E, Diaz-Loaiza A, Gao J, Ke Q, Aerts JCJH (2020) Hard or soft flood adaptation? advantages of a hybrid strategy for Shanghai. Glob Environ Chang 61:102037. https://doi.org/10.1016/j.gloenvcha.2020.102037 
Egbert GD, Erofeeva SY (2002) Efficient inverse modeling of barotropic ocean tides. J Atmos Ocean Technol 19(20):183-204

Emanuel KA (2013) Downscaling CMIP5 climate models shows increased tropical cyclone activity over the 21st century. Proc Natl Acad Sci 110(30):12219-12224. https://doi.org/10.1073/pnas.1301293110

Feng X, Yin B, Yang D, William P (2011) The effect of wave-induced radiation stress on storm surge during Typhoon Saomai (2006). Acta Oceanol Sin 30(3):20-26. https://doi.org/10.1007/s13131-011-0115-6

Fosser G, Kendon E, Chan S, Lock A, Roberts N, Bush M (2020) Optimal configuration and resolution for the first convection-permitting ensemble of climate projections over the United Kingdom. Int J Climatol 40(7):3585-3606. https://doi.org/10.1002/joc.6415

Ge J, Ding P, Chen C, Hu S, Fu G, Wu L (2013) An integrated east china sea-Changjiang Estuary model system with aim at resolving multi-scale regional-shelf-estuarine dynamics. Ocean Dyn 63(8):881900. https://doi.org/10.1007/s10236-013-0631-3

Gutmann ED, Rasmussen RM, Liu C, Ikeda K, Bruyere CL, Done JM, Garrè L, Friis-Hansen P, Veldore V (2018) Changes in hurricanes from a 13-Yr convection-permitting pseudo-global warming simulation. J Clim 31(9):3643-3657. https://doi.org/10.1175/JCLI-D-17-0391.1

Hall TM, Kossin JP (2019) Hurricane stalling along the North American coast and implications for rainfall. Npj Clim Atmos Sci 2(1):1-9. https://doi.org/10.1038/s41612-019-0074-8

Hanson S, Nicholls R, Herweijer SHJCC (2011) A global ranking of port cities with high exposure to climate extremes. Clim Chang 104(1):89-111

He X-C, Yang T-L, Shen S-L, Xu Y-S, Arulrajah A (2019) Land subsidence control zone and policy for the environmental protection of Shanghai. Int J Environ Res Public Health 16(15):2729. https://doi.org/10. 3390/ijerph16152729

Holland G, Bruyère CL (2014) Recent intense hurricane response to global climate change. Clim Dyn 42(34):617-627. https://doi.org/10.1007/s00382-013-1713-0

Holland GJ, Belanger JI, Fritz A (2010) A revised model for radial profiles of hurricane winds. Mon Weather Rev 138(12):4393-4401. https://doi.org/10.1175/2010MWR3317.1

IPCC 2019 Chapter 4: Sea Level Rise and Implications for Low Lying Islands, Coasts and Communities Coordinating

Irish JL, Resio DT, Ratcliff JJ (2008) The influence of storm size on hurricane surge. J Phys Oceanogr 38(9):2003-2013. https://doi.org/10.1175/2008JPO3727.1

Jones CD, Hughes JK, Bellouin N, Hardiman SC, Jones GS, Knight J, Liddicoat S, O'Connor FM, Andres RJ, Bell C, Boo K-O, Bozzo A, Butchart N, Cadule P, Corbin KD, Doutriaux-Boucher M, Friedlingstein P, Gornall J, Gray L, Halloran PR, Hurtt G, Ingram WJ, Lamarque J-F, Law RM, Meinshausen M, Osprey S, Palin EJ, Parsons Chini L, Raddatz T, Sanderson MG, Sellar AA, Schurer A, Valdes P, Wood N, Woodward S, Yoshioka M, Zerroukat M (2011) The HadGEM2-ES implementation of CMIP5 centennial simulations. Geosci. Model Dev. 4(3):543-570

Kernkamp HWJ, Van Dam A, Stelling GS, De Goede ED (2011) Efficient scheme for the shallow water equations on unstructured grids with application to the Continental Shelf. Ocean Dyn 61(8):11751188. https://doi.org/10.1007/s10236-011-0423-6

Kirezci E, Young IR, Ranasinghe R, Muis S, Nicholls RJ, Lincke D, Hinkel J (2020) Projections of globalscale extreme sea levels and resulting episodic coastal flooding over the 21 st Century. Sci Rep 10(1):112. https://doi.org/10.1038/s41598-020-67736-6

Knutson TR, McBride JL, Chan J, Emanuel K, Holland G, Landsea C, Held I, Kossin JP, Srivastava AK, Sugi M (2010) Tropical cyclones and climate change. Nat Geosci 3(3):157-163. https://doi.org/10. 1038/ngeo 779

Knutson TR, Sirutis JJ, Zhao M, Tuleya RE, Bender M, Vecchi GA, Villarini G, Chavas D (2015) Global projections of intense tropical cyclone activity for the late twenty first century from dynamical downscaling of CMIP5/RCP4.5 scenarios. J Clim 28(18):7203-7224

Kossin JP (2018) A global slowdown of tropical-cyclone translation speed. Nature 558(7708):104-107. https://doi.org/10.1038/s41586-018-0158-3

Kossin JP, Emanuel KA, Vecchi GA (2014) The poleward migration of the location of tropical cyclone maximum intensity. Nature 509(7500):349-352. https://doi.org/10.1038/nature13278

Lagmay AMF, Agaton RP, Bahala MAC, Briones JBLT, Cabacaba KMC, Caro CVC, Dasallas LL, Gonzalo LAL, Ladiero CN, Lapidez JP, Mungcal MTF, Puno JVR, Ramos MMAC, Santiago J, Suarez JK, Tablazon JP (2015) Devastating storm surges of Typhoon Haiyan. Int J Disaster Risk Reduct 11:1-12. https://doi.org/10.1016/j.ijdrr.2014.10.006

Leduc M, Laprise R (2009) Regional climate model sensitivity to domain size. Clim Dyn 32(6):833-854. https://doi.org/10.1007/s00382-008-0400-Z

Liang D, Zhao X, Soga K (2020) Simulation of overtopping and seepage induced dike failure using twopoint MPM. Soils Found. https://doi.org/10.1016/j.sandf.2020.06.004 
Lin N, Emanuel K, Oppenheimer M, Vanmarcke E (2012) Physically based assessment of hurricane surge threat under climate change. Nat Clim Chang 2(6):462-467. https://doi.org/10.1038/nclimate1389

Marsooli R, Lin N, Emanuel K, Feng K (2019) Climate change exacerbates hurricane flood hazards along US Atlantic and Gulf coasts in spatially varying patterns. Nat Commun 10(1):1-9. https://doi.org/10. 1038/s41467-019-11755-z

Matte D, Laprise R, Thériault JM, Lucas-Picher P (2017) Spatial spin-up of fine scales in a regional climate model simulation driven by low-resolution boundary conditions. Clim Dyn 49(1-2):563-574. https:// doi.org/10.1007/s00382-016-3358-2

Mbengue C, Schneider T (2017) Storm-track shifts under climate change: toward a mechanistic understanding using baroclinic mean available potential energy. J Atmos Sci 74(1):93-110. https://doi. org/10.1175/JAS-D-15-0267.1

Mei W, Xie S-P (2016) Intensification of landfalling typhoons over the northwest Pacific since the late 1970s. Nat Geosci 9(10):753-757. https://doi.org/10.1038/ngeo2792

Ministry of Natural Resource of China (2019) China Sea Level Rising Bulletin

Moss RH, Edmonds JA, Hibbard KA, Manning MR, Rose SK, van Vuuren DP, Carter TR, Emori S, Kainuma M, Kram T, Meehl GA, Mitchell JFB, Nakicenovic N, Riahi K, Smith SJ, Stouffer RJ, Thomson AM, Weyant JP, Wilbanks TJ (2010) The next generation of scenarios for climate change research and assessment. Nature 463(7282):747-756. https://doi.org/10.1038/nature08823

Mousavi ME, Irish JL, Frey AE, Olivera F, Edge BL (2011) Global warming and hurricanes: the potential impact of hurricane intensification and sea level rise on coastal flooding. Clim Change 104(34):575-597. https://doi.org/10.1007/s10584-009-9790-0

Needham HF, Keim BD, Sathiaraj D (2015) A review of tropical cyclone-generated storm surges: global data sources, observations, and impacts. Rev Geophys 53(2):545-591. https://doi.org/10.1002/ 2014RG000477

Pham NTT, Nguyen QH, Ngo AD, Le HTT, Nguyen CT (2018) Investigating the impacts of typhooninduced floods on the agriculture in the central region of Vietnam by using hydrological models and satellite data. Nat Hazards 92(1):189-204. https://doi.org/10.1007/s11069-018-3202-6

Rego JL, Li C (2009) On the importance of the forward speed of hurricanes in storm surge forecasting numerical study. Geophys Res Lett. https://doi.org/10.1029/2008GL036953

Resio DT, Westerink JJ (2008) Modeling the physics of storm surges. Phys Today 61(9):33-38. https:// doi.org/10.1063/1.2982120

Shimozono T, Tajima Y, Kumagai K, Arikawa T, Oda Y, Shigihara Y, Mori N, Suzuki T (2020) Coastal impacts of super typhoon Hagibis on greater Tokyo and Shizuoka areas, Japan. Coast Eng J 62(2):129-145. https://doi.org/10.1080/21664250.2020.1744212

Smith SD, Banke EG (1975) Variation of the sea surface drag coefficient with wind speed. R Meteorol Soc q.j. https://doi.org/10.1002/qj.49710142920

SSB: Shanghai statistic yearbook 2019

Symonds A, Vijverberg T, Post S, Spek B-J, Henrotte J (2017) Comparison between MIKE 21 FM, Delft3D and Delft3D FM flow models of Western Port Bay, Australia. In: International conference on coastal engineering 2016, Antalya, Turkey

Tay CWJ, Yun SH, Chin ST, Bhardwaj A, Jung J, Hill EM (2020) Rapid flood and damage mapping using synthetic aperture radar in response to Typhoon Hagibis, Japan. Sci Data 7(1):1-9. https:// doi.org/10.1038/s41597-020-0443-5

Taylor KE, Stouffer RJ, Meehl GA (2012) An Overview of CMIP5 and the experiment design. Bull Am Meteorol Soc 93(4):485-498. https://doi.org/10.1175/BAMS-D-11-00094.1

Van der Meer JW, Janssen JPFM (2002) Wave run-up and wave overtopping at dikes. Techinical report

Verheij H, Visser P, Förster U (2009) Analysis of Chinese dike breaches along the Yangtze River and tributaries. Deltares, Delft

Visser P (1998a) Breach erosion in sand-dikes. Proc 26th Int. Conf. Coast. Eng 3:3516-3528

Visser PJ (1998b) Breach growth in sand-dikes. PhD Thesis, Delft University of Technology

Walsh KJE, McBride JL, Klotzbach PJ, Balachandran S, Camargo SJ, Holland G, Knutson TR, Kossin JP, Lee T, Sobel A, Sugi M (2016) Tropical cyclones and climate change. Wiley Interdiscip Rev Clim Chang 7(1):65-89. https://doi.org/10.1002/wcc.371

Wang J, Xu S, Ye M, Huang J (2011) The MIKE model application to overtopping risk assessment of seawalls and levees in Shanghai. Int J Disaster Risk Sci 2(4):32-42. https://doi.org/10.1007/ s13753-011-0018-3

Wang J, Gao W, Xu S, Yu L (2012) Evaluation of the combined risk of sea level rise, land subsidence, and storm surges on the coastal areas of Shanghai, China. Clim Change 115(3-4):537-558. https:// doi.org/10.1007/s10584-012-0468-7 
Wang J, Yi S, Li M, Wang L, Song C (2018) Effects of sea level rise, land subsidence, bathymetric change and typhoon tracks on storm flooding in the coastal areas of Shanghai. Sci Total Environ 621:228-234. https://doi.org/10.1016/j.scitotenv.2017.11.224

Warner NN, Tissot PE (2012) Storm flooding sensitivity to sea level rise for Galveston bay. Texas Ocean Eng 44:23-32. https://doi.org/10.1016/j.oceaneng.2012.01.011

Woodruff JD, Irish JL, Camargo SJ (2013) Coastal flooding by tropical cyclones and sea-level rise. Nature 504(7478):44-52. https://doi.org/10.1038/nature12855

Xu Y (2006) Chinese meteorological disaster in Shanghai (in Chinese). In: Wen K (ed) China Meteorological Publisher, Beijing, China. http://www.cma.gov.cn/ (ISBN:7-5029-4228-9)

Yamanaka Y, Shibata R, Tajima Y, Okami N (2020) Inundation Characteristics in Arida City Due to Overtopping Waves Induced by 2018 Typhoon Jebi. APAC 2019. Springer Singapore, Singapore., pp 199-206

Yin J, Yu D, Yin Z, Wang J, Xu S (2013b) Modelling the combined impacts of sea-level rise and land subsidence on storm tides induced flooding of the Huangpu River in Shanghai, China. Clim Change 119:919-932

Yin J, Yin Z, Xu S (2013a) Composite risk assessment of typhoon-induced disaster for China's coastal area. Nat Hazards 69(3):1423-1434. https://doi.org/10.1007/s11069-013-0755-2

Yin J, Jonkman S, Lin N, Yu D, Aerts J, Wilby R, Pan M, Wood E, Bricker J, Ke Q, Zeng Z, Zhao Q, Ge J, Wang J (2020) Flood risks in sinking delta cities: time for a reevaluation? Earth's Future. https://doi. org/10.1029/2020EF001614

Zhang Y, Meng Z, Zhang F, Weng Y (2014) Predictability of tropical cyclone intensity evaluated through 5 -yr forecasts with a convection-permitting regional-scale model in the atlantic basin. Weather Forecast 29(4):1003-1023. https://doi.org/10.1175/WAF-D-13-00085.1

Zijlema M (2010) Computation of wind-wave spectra in coastal waters with SWAN on unstructured grids. Coast Eng 57(3):267-277. https://doi.org/10.1016/j.coastaleng.2009.10.011

Zijlema M, Van Vledder GP, Holthuijsen LH (2012) Bottom friction and wind drag for wave models. Coast Eng 65:19-26. https://doi.org/10.1016/j.coastaleng.2012.03.002

Zong Y, Chen X (2002) Typhoon hazards in the shanghai area. Disasters 23(1):66-80. https://doi.org/10. $1111 / 1467-7717.00105$

Publisher's Note Springer Nature remains neutral with regard to jurisdictional claims in published maps and institutional affiliations.

\title{
Authors and Affiliations
}

Qian Ke ${ }^{1}$ - Jiangshan Yin ${ }^{2}$ Jeremy D. Bricker ${ }^{1,3}$ (Dicholas Savage ${ }^{4}$. Erasmo Buonomo ${ }^{4}$. Qinghua Ye ${ }^{1,5} \cdot$ Paul Visser $^{1}$. Guangtao Dong ${ }^{6}$. Shuai Wang ${ }^{7}$. Zhan Tian $^{8} \cdot$ Laixiang Sun $^{9,10} \cdot$ Ralf Toumi $^{7}$. Sebastiaan N. Jonkman ${ }^{1}$

\author{
Qian Ke \\ Q.ke@tudelft.nl \\ Jiangshan Yin \\ jsyin@nhri.cn \\ Nicholas Savage \\ nicholas.savage@metoffice.gov.uk \\ Erasmo Buonomo \\ erasmo.buonomo@metoffice.gov.uk \\ Qinghua Ye \\ Qinghua.ye@deltares.nl \\ Paul Visser \\ P.J.visser@tudelft.nl \\ Guangtao Dong \\ gtdong@163.com
}


Shuai Wang

shuai.wang@imperial.ac.uk

Laixiang Sun

1sun123@umd.edu

Ralf Toumi

r.toumi@imperial.ac.uk

Sebastiaan N. Jonkman

S.N.Jonkman@tudelft.nl

1 Department of Hydraulic Engineering, Faculty of Civil Engineering and Geosciences, Delft University of Technology, Delft, The Netherlands

2 Dam Safety Management Centre of Ministry of Water Resources, Nanjing Hydraulic Research Institute, Nanjing, China

3 Department of Civil and Environmental Engineering, University of Michigan, Ann Arbor, MI, USA

4 Met Office Hadley Centre, Exeter, UK

5 Deltares, Delft, the Netherlands

6 Shanghai Climate Centre, Shanghai Meteorological Service, Shanghai, China

7 Department of Physics, Imperial College London, London SW7 2BU, UK

8 Department of Environmental Science and Engineering, School of Environmental Science and Engineering, Southern University of Science and Technology, Shenzhen, China

9 Department of Geographical Sciences, University of Maryland, College Park, MD, USA

10 School of Finance and Management, SOAS University of London, London, UK 